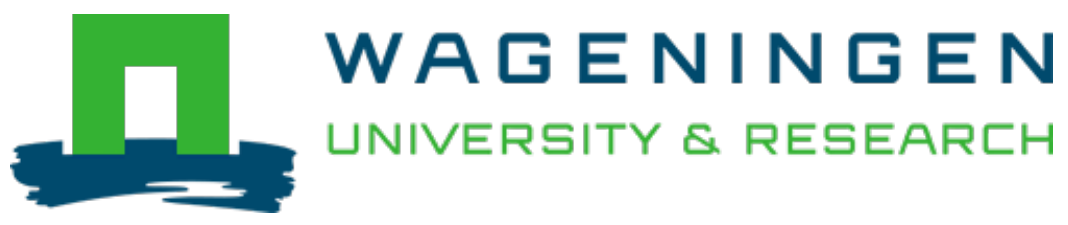

\author{
Mapping the patchy legislative landscape of non-native tree species in Europe \\ Forestry \\ Pötzelsberger, Elisabeth; Lapin, Katharina; Brundu, Giuseppe; Adriaens, Tim; Andonovski, Vlatko et al \\ https://doi.org/10.1093/forestry/cpaa009
}

This publication is made publicly available in the institutional repository of Wageningen University and Research, under the terms of article $25 \mathrm{fa}$ of the Dutch Copyright Act, also known as the Amendment Taverne. This has been done with explicit consent by the author.

Article $25 \mathrm{fa}$ states that the author of a short scientific work funded either wholly or partially by Dutch public funds is entitled to make that work publicly available for no consideration following a reasonable period of time after the work was first published, provided that clear reference is made to the source of the first publication of the work.

This publication is distributed under The Association of Universities in the Netherlands (VSNU) 'Article $25 \mathrm{fa}$ implementation' project. In this project research outputs of researchers employed by Dutch Universities that comply with the legal requirements of Article $25 \mathrm{fa}$ of the Dutch Copyright Act are distributed online and free of cost or other barriers in institutional repositories. Research outputs are distributed six months after their first online publication in the original published version and with proper attribution to the source of the original publication.

You are permitted to download and use the publication for personal purposes. All rights remain with the author(s) and / or copyright owner(s) of this work. Any use of the publication or parts of it other than authorised under article $25 \mathrm{fa}$ of the Dutch Copyright act is prohibited. Wageningen University \& Research and the author(s) of this publication shall not be held responsible or liable for any damages resulting from your (re)use of this publication.

For questions regarding the public availability of this publication please contact openscience.library@wur.nl 


\section{Mapping the patchy legislative landscape of non-native tree species in Europe}

Elisabeth Pötzelsberger ${ }^{1, *}$, Katharina Lapin ${ }^{2}$, Giuseppe Brundu ${ }^{3}$, Tim Adriaens ${ }^{4}$, Vlatko Andonovski ${ }^{5}$, Siniša Andrašev ${ }^{6}$, Jean-Charles Bastien ${ }^{7}$, Robert Brus ${ }^{8}$, Milić Čurović ${ }^{9}$, Željka Čurović $^{10}$, Branislav Cvjetković ${ }^{11}$, Martina Đodan ${ }^{12}$, Juan M. Domingo-Santos ${ }^{13}$, Anna Gazda ${ }^{14}$, Jean-Marc Henin ${ }^{15}$, Cornelia Hernea ${ }^{16}$, Bo Karlsson ${ }^{17}$, Ljiljana Keča ${ }^{18}$, Srđan Keren ${ }^{14,11}$, Zsolt Keserü ${ }^{19}$, Thomai Konstantara ${ }^{20}$, Johan Kroon ${ }^{17,21}$, Nicola La Porta ${ }^{22}$, Vasyl Lavnyy ${ }^{23}$, Dagnija Lazdina ${ }^{24}$, Aljona Lukjanova ${ }^{25}$, Tiit Maaten ${ }^{26}$, Palle Madsen ${ }^{27}$, Dejan Mandjukovski ${ }^{28}$, Francisco J. Marín Pageo ${ }^{13}$, Vitas Marozas ${ }^{29}$, Antonin Martinik ${ }^{30}$, William L. Mason ${ }^{31}$, Frits Mohren ${ }^{32}$, Maria Cristina Monteverdi ${ }^{33}$, Charalambos Neophytou ${ }^{1}$, Pat Neville ${ }^{34}$, Valeriu-Norocel Nicolescu ${ }^{35}$, Per Holm Nygaard ${ }^{36}$, Christophe Orazio ${ }^{37,38}$, Taras Parpan $^{39}$, Sanja Perić ${ }^{12}$, Krasimira Petkova ${ }^{40}$,

Emil Borissov Popov ${ }^{41}$, Mick Power ${ }^{34}$, Károly Rédei ${ }^{42}$, Matti Rousi ${ }^{43}$, Joaquim S. Silva ${ }^{44,45}$, Ahmet Sivacioğlu ${ }^{46}$, Michalis Socratous ${ }^{47}$, Lina Straigytè ${ }^{29}$, Josef Urban ${ }^{30,48}$, Kris Vandekerkhove ${ }^{49}$, Radosław Wąsik ${ }^{14}$, Marjana Westergren ${ }^{50}$, Thomas Wohlgemuth ${ }^{51}$, Tiina Ylioja ${ }^{43}$ and Hubert Hasenauer ${ }^{1}$

${ }^{1}$ Institute of Silviculture, University of Natural Resources and Life Sciences, Vienna (BOKU), Peter-Jordan-Straße 82, 1190 Vienna, Austria

${ }^{2}$ Austrian Federal Research Centre for Forests, Natural Hazards and Landscape (BFW), Seckendorff-Gudent-Weg 8, 1131 Vienna, Austria ${ }^{3}$ Department of Agriculture, University of Sassari, Viale Italia 39, 07100 Sassari, Italy

${ }^{4}$ Wildlife Management and Invasive Species, ?Research Institute for Nature and Forest (INBO), Havenlaan 88 bus 73,1000 Bruxelles, Belgium

5 “HANS EM” Faculty of Forest Sciences, Landscape Architecture and Environmental Engineering, University Ss. Cyril and Methodius, P.O. Box 235, Skopje 1000, North Macedonia

${ }^{6}$ Institute of Lowland Forestry and Environment, University of Novi Sad, Antona Čehova 13, 21000 Novi Sad, Serbia

${ }^{7}$ INRAE Centre Val de Loire, INRAE (National Research institute for Agriculture, Food and Environment), 2163 Avenue de la Pomme de Pin, 45075 Orleans Cedex 2, France

${ }^{8}$ Biotechnical Faculty, University of Ljubljana, Jamnikarjeva 101, 1000 Ljubljana, Slovenia

${ }^{9}$ Biotechnical Faculty, University of Montenegro, Mihaila Lalica 1, 81000 Podgorica, Montenegro

${ }^{10}$ Ministry of Sustainable Development and Tourism, IV proleterske brigade 19, 81000 Podgorica, Montenegro

${ }^{11}$ Faculty of Forestry, University of Banja Luka, Bulevar vojvode Stepe Stepanovica 75A, 51000 Banja Luka, Bosnia and Herzegowina

${ }^{12}$ Division for Silviculture, Croatian Forest Research Institute, Cvjetno naselje 41, 10450 Jastrebarsko, Croatia

${ }^{13}$ Agroforestry Science, University of Huelva, ETSI, Campus de El Carmen, 21071 Huelva, Spain

${ }^{14}$ Faculty of Forestry, University of Agriculture, Al. 29 Listopada 46, 31-425 Kraków, Poland

${ }^{15}$ Laboratory of Wood Technology, Public Service of Wallonia (SPW), Avenue M. Juin 23, 5030 Gembloux, Belgium

${ }^{16}$ Faculty of Horticulture and Forestry, Banat's University of Agricultural Sciences and Veterinary Medicine "King Michael I of Romania" from Timisoara, 300645 Timisoara, Romania

${ }^{17}$ Skogforsk, Ekebo 2250, 26890 Svalöv, Sweden

${ }^{18}$ Department of Forestry, University of Belgrade, 1, Kneza Viseslava Street, 11030 Belgrade, Serbia

${ }^{19}$ Forest Research Institute, National Agricultural Research and Innovation Centre, Farkassziget 3, H-4150 Püspökladány, Hungary

${ }^{20}$ Faculty of Agriculture, Forestry and Natural Environment, Aristotle University of Thessaloniki, 54124 Thessaloniki, Greece

${ }^{21}$ Department of Forestry and Wood Technology, Linnaeus University, SE-351 95, Sweden

${ }^{22}$ Department of Sustainable Agroecosystems and Bioresources, Fondazione Edmund Mach, Via E. Mach 1, 38010 San Michele all'Adige, Italy

${ }^{23}$ Department of Silviculture, Ukrainian National Forestry University, Gen. Chuprynky Street 103, 79057 Lviv, Ukraine

${ }^{24}$ Latvian State Forest Research Institute Silava, Riga street 111, Salaspils, LV-2169, Latvia

${ }^{25}$ Depertment of Environmental Toxicology, The National Institute of Chemical Physics and Biophysics (NICPB), Akadeemia tee 23, 12618 Tallinn, Estonia

${ }^{26}$ Institute of Forestry and Rural Engineering, Estonian University of Life Sciences, Fr. R. Kreutzwaldi 5, 51006 Tartu, Estonia ${ }^{27}$ InNovaSilva ApS, HØjen Tang 80, 7100 Vejle, Denmark

(c) The Author(s) 2020. Published by Oxford University Press on behalf of Institute of Chartered Foresters. All rights reserved. For permissions, please e-mail: journals.permissions@oup.com. 


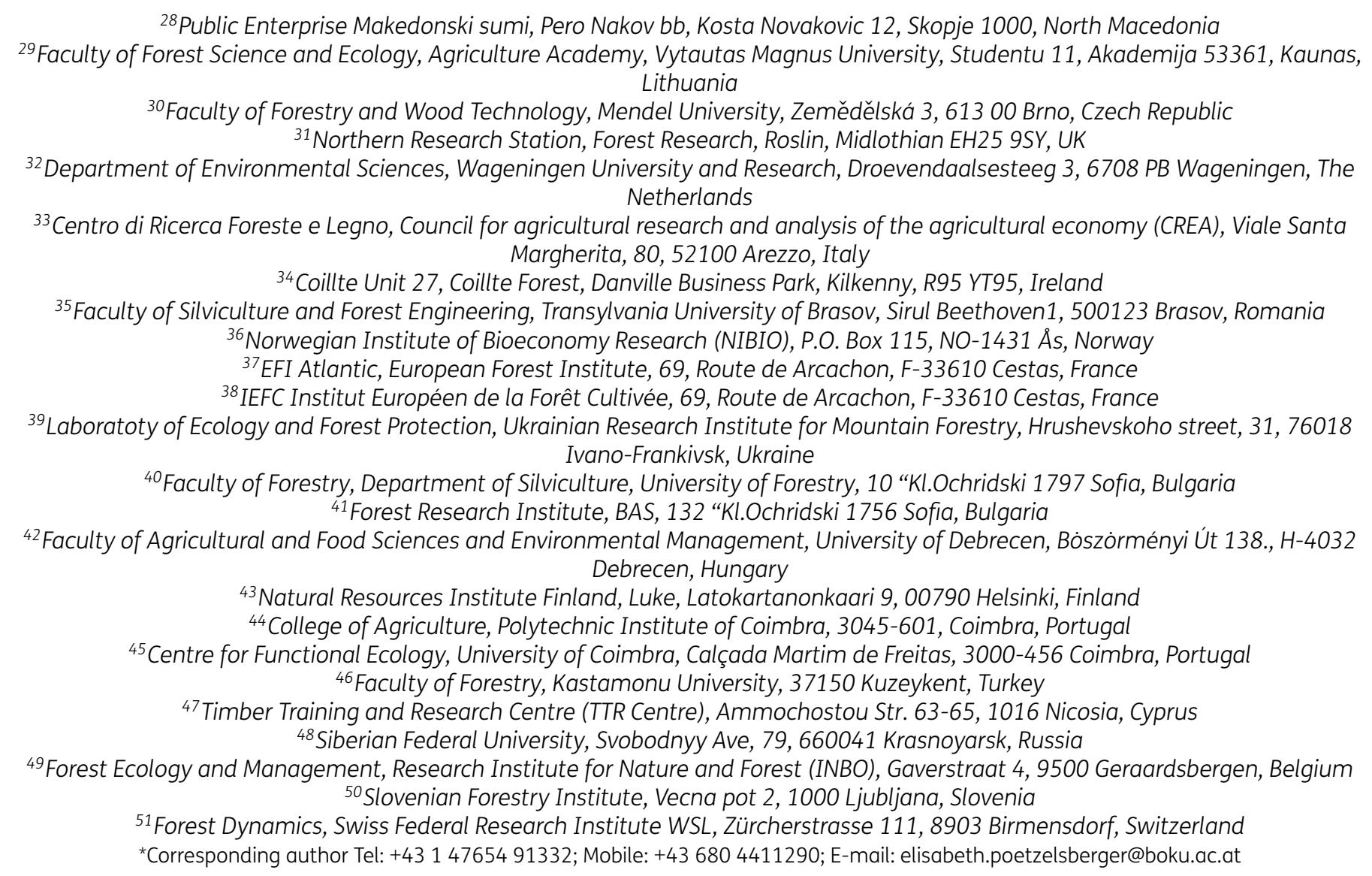

Received 1 August 2019

\begin{abstract}
Europe has a history rich in examples of successful and problematic introductions of trees with a native origin outside of Europe (non-native trees, NNT). Many international legal frameworks such as treaties and conventions and also the European Union have responded to the global concern about potential negative impacts of NNT that may become invasive in natural ecosystems. It is, however, national and regional legislation in particular that affects current and future management decisions in the forest sector and shapes the landscapes of Europe. We identified all relevant legal instruments regulating NNT, the different legal approaches and the regulatory intensity in 40 European countries (no microstates). Information on hard and effective soft law instruments were collected by means of a targeted questionnaire and consultation of international and national legislation information systems and databases. In total, 335 relevant legal instruments were in place in June/July 2019 to regulate the use of NNT in the investigated 116 geopolitical legal units (countries as well as sub-national regions with their own legislation). Countries and regions were empirically categorized according to ad hocdefined legislation indicators. These indicators pay respect to the general bans on the introduction of non-native species, the generally allowed and prohibited NNT, approval mechanisms and specific areas or cases where NNT are restricted or prohibited. Our study revealed a very diverse landscape of legal frameworks across Europe, with a large variety of approaches to regulating NNT being pursued and the intensity of restriction ranging from very few restrictions on species choice and plantation surface area to the complete banning of NNT from forests. The main conclusion is that there is a clear need for more co-ordinated, science-based policies both at the local and international levels to enhance the advantages of NNT and mitigate potential negative effects.
\end{abstract}

\section{Introduction}

Trees with a native origin outside of Europe (alien sensu (Essl et al., 2018) and hereinafter referred to as non-native trees; abbreviated NNT) have long been used in European landscapes, forestry and culture. NNT have been introduced for various reasons such as ornamental purposes, food production, land reclamation, soil stabilization and timber production. In recent years, the potential of employing NNT for climate change adaptation and mitigation is increasingly explored (Bolte et al., 2009; Vor et al., 2015; Brang et al., 2016; Correia et al., 2018; Stanturf et al., 2018). Commitments from the Paris Agreement (COP21 of the UNFCCC) spur 
forest plantations worldwide, which in turn can be expected to lead to an increase in the area of NNT, since almost 20 per cent of plantations around the world are composed of NNT (with much higher local proportions in South America, Oceania, South Africa and East Africa; Payn et al., 2015).

European forests currently consist of $\sim 4$ per cent or 8.5 Mha non-native tree species, with large regional differences (Pötzelsberger, 2018; Brus et al., 2019). While the first NNT were introduced to Europe by ancient societies, many more tree species were discovered mainly in the Americas, Australia and Eastern Asia and imported during the last 400 years (Nyssen et al., 2016; Pötzelsberger, 2018). Some of the most common NNT species are black locust (Robinia pseudoacacia L.), Sitka spruce (Picea sitchensis (Bong.) Carr.), Douglas-fir (Pseudotsuga menziesii (Mirb.) Franco) and various Eucalyptus species.

The use of NNT can also be highly controversial as NNT can cause significant environmental changes as part of large-scale plantations or when they spread beyond the place of introduction into natural ecosystems. Several NNT are known to compete with native species and can cause irreversible changes to many European habitats. Black locust and tree of heaven (Ailanthus altissima (Miller) Swingle), for example, are widely considered to be invasive and produce negative impacts according to the commonly agreed definitions of 'invasive alien species (IAS)' (Blackburn et al., 2011; Wilson et al., 2014, 2018; Medina-Villar et al., 2015; Vítková et al., 2017).

For EU and non-EU Member States, a number of international treaties, legally non-binding conventions and self-regulatory tools or standards are of importance and provide guidance on the use and management of NNT. These legal instruments can be distinguished between (1) instruments addressing NNT in general and (2) instruments aiming specifically at regulating IAS including invasive NNT.

Instruments addressing NNT in general mainly comprise standards, guidelines, criteria and indicators for sustainable forest management. They have been developed over the past few decades by intergovernmental processes such as Forest Europe (Ministerial Conference on the Protection of Forests in Europe, MCPFE), international organizations, forest certification schemes (e.g. FSC, PEFC) (Masiero et al., 2015) and national governments. These tools apply to all forests, including planted forests, and have resulted in forestry being recognized as a form of sustainable land use as well as being essential for combatting climate change. Most certification standards refer to the use of appropriate provenances, varieties and species for afforestation and reforestation. Native species are always preferred, but NNT species are allowed where they are substantially superior to native species for achieving forest management objectives (Stupak et al., 2011). The Alpine Convention of 1991, a multinational treaty signed and ratified by the European Union and the eight countries sharing parts or the entirety of their territory with the Alps, also falls into this group. Its annexed 'Mountain Forests' Protocol ('Protocol on the implementation of the Alpine Convention relating to mountain forests') of 1996, in Article 1 commits countries to ensure that 'the forest reproduction material used is indigenous'. The 'Mountain Forests' Protocol, one among eight protocols that implement specific measures for the protection of the Alps, so far has been ratified by Austria, Germany, France, Italy, Liechtenstein and Slovenia, was signed but not ratified by Switzerland and Monaco and has not been signed so far by the EU.

Instruments aiming specifically at regulating IAS comprise a number of conventions addressing various global assets that have influenced national policies on the topic of invasive nonnative species: the International Plant Protection Convention (IPPC) of 1951, the Convention on International Trade in Endangered Species of Wild Fauna and Flora (CITES) signed in 1973, the Convention on the Conservation of European Wildlife and Natural Habitats (Bern Convention) of the Council of Europe of 1979 and the United Nations Convention on Biological Diversity (CBD) of 1992, but also the regionally applicable Framework Convention on the Protection and Sustainable Development of the Carpathians (Carpathian Convention) of 2003.

Notably, the CBD states in Article 8(h) that 'each Contracting Party shall, as far as possible and as appropriate, prevent the introduction of, control or eradicate those alien species which threaten ecosystems, habitats or species'. Since 2001 (UNEP/CBD/SBSTTA/6/INF/11, 26 February 2001), the voluntary introduction of invasive NNT in forestry has been highlighted as an 'important source of biological invasions'. Under the influence of the CBD, the Second Ministerial Conference on the Protection of Forests in Europe, MCPFE (16-17 June 1993, Helsinki/Finland) (Forest Europe, 1993) stated that 'native species and local provenances should be preferred where appropriate. The use of species, provenances, varieties or ecotypes outside their natural range should be discouraged where their introduction would endanger important/valuable indigenous ecosystems, flora and fauna. Introduced species may be used when their potential negative impacts have been assessed and evaluated over sufficient time, and where they provide more benefits than do indigenous ones in terms of wood production and other functions. Whenever introduced species are used to replace local ecosystems, sufficient action should be taken at the same time to conserve native flora and fauna'.

The governing body of the IPPC, the Interim Commission on Phytosanitary Measures (ICPM), addressed the topic of biosafety at its second meeting (ICPM 2) in 1999, concluding that the concept of IAS had considerable implications for the IPPC and that coordination between government authorities at the national and international levels was required to avoid conflicting views in different fora (FAO, 1999). As a result of these discussions, an informal open-ended working group was established to consider issues relating to genetically modified organisms, biosafety and IAS. The ICPM states that species which may be invasive and which directly or indirectly affect plants or plant products should be assessed, monitored and managed according to the IPPC provisions if necessary.

In 1997, the CITES Resolution Conference 13.10 (Rev. CoP14) on 'Trade in invasive alien species' recommended taking the issue of invasive species into consideration when developing national legislation and regulations dealing with trade in live animals or plants.

The Bern Convention adopted the European Strategy on Invasive Alien Species, which aims to provide precise guidance to European governments on IAS issues, in 2003 (Genovesi and Shine, 2004); in 2017, it adopted the Code of Conduct for Invasive Alien Trees (Brundu and Richardson, 2016, 2017). The Code of Conduct recommends that for each new NNT species 
or provenance that is planned for introduction and has not already been evaluated, those introducing the new NNT or planning new planted forests should conduct a risk assessment or risk analysis to take into account the associated opportunities and risks.

The Carpathian Convention, signed and ratified by Czech Republic, Hungary, Poland, Rumania, Serbia and Ukraine, in contrast to the Alpine Convention, calls for 'policies aiming at the prevention of introduction of alien invasive species'. Besides, the Protocol on Sustainable Forest Management to the Framework Convention on the Protection and Sustainable Development of the Carpathians (not signed by Poland so far) emphasizes and details the promotion of close to nature forestry including the conservation and restoration of a native species composition.

In the European Union, forest policies are implemented by Member States within a clearly defined framework of established ownership rights and with a long history of national and regional laws and regulations based on long-term planning. Although the EU Treaties make no provision for a common forest policy, there is a long history of EU measures supporting certain forest-related activities, coordinated with Member States mainly through the Standing Forestry Committee (European Commission, 2003).

Land used for forests and agroforestry is affected by a wide range of community policies and initiatives arising from various EU sectoral policies (e.g. Schmithüsen et al., 2000). For several decades, environmental forest functions have been increasingly attracting attention, primarily in the context of the protection of biodiversity and, more recently, in the context of climate change impacts and mitigation. In the public perception, apart from the traditional production of wood and non-wood forest products, forests are increasingly valued for their role as public amenities, biodiversity reservoirs, regulators of climate and local weather, sources of clean water, protection against natural disasters and renewable energy sources (European Commission, 2003).

At the European Union level, mainly the following three legal instruments are relevant to the introduction, use and management of NNT: (1) Council Directive 1999/105/EC of 22 December 1999 on the marketing of forest reproductive material, (2) Council Directive 92/43/EEC of 21 May 1992 on the conservation of natural habitats and of wild fauna and flora (known as the 'Habitats Directive') and (3) Regulation (EU) No. 1143/2014 on the prevention and management of the introduction and spread of IAS.

Council Directive 1999/105/EC in Annex I lists tree species and artificial hybrids that are important for forestry purposes. Among them are several NNT like black locust, Douglas-fir, Monterey pine (Pinus radiata D. Don) and others. EU Member States are allowed to modify this Annex I list when adopting the measures of the Directive, and the list's legal implications can also differ between countries.

The Habitats Directive in Article 22.b states that EU Member States shall 'ensure that the deliberate introduction into the wild of any species which is not native to their territory is regulated and, if they consider it necessary, prohibit such introduction.' This directive forms the cornerstone of Europe's nature conservation policy along with the 'Birds Directive' and establishes the EUwide 'Natura 2000' network of protected areas to be safeguarded against potentially damaging developments.
The choice of tree species in a Natura 2000 site and the degree to which the presence of certain species may be promoted or limited depends on the ecological requirements of the species and habitat types for which the site has been designated as well as on the site's specific conservation objectives (Campagnaro et al., 2018). In sites with the objective of improving the degree of conservation of a particular habitat type or species, a possible conservation measure may be to attempt to reduce the area occupied by non-native species in order to restore the continuity of a natural habitat or its structure. On the other hand, in sites whose objective is to maintain forests in their current condition and distribution, it may be possible to retain existing non-native species as long as this does not impede the achievement of the site's conservation objective. The Natura 2000 sites cover 18 per cent of the European land area (European Commission Directorate-General for Environment, 2019), including 37.5 Mha of forests, and have become a key instrument within the overall EU nature conservation agenda. However, the Member States handle NNT management in Natura 2000 sites in different ways, and this circumstance will also be partly covered by this study.

Regulation (EU) No. 1143/2014 introduced a ban at EU level on intentionally or accidentally introducing into the Union as well as on reproducing, growing, transporting, buying, selling, using, exchanging, keeping and releasing IAS of Union concern. IAS to which the ban applies are specified in the 'List of invasive alien species of Union concern' (the 'Union list'), which was first published in 2016 (Commission Implementing Regulation (EU) $2016 / 1141$ of 13 July 2016). Following the update of the Union list in 2019 (Commission Implementing Regulation (EU) 2019/1262 of 25 July 2019), the first four alien tree species, tree of heaven, Port Jackson wattle (Acacia saligna (Labill.) H.L.Wendl.), a mesquite (Prosopis juliflora (Sw.) DC.) and Chinese tallow (Triadica sebifera (L.) Small), are now officially banned in the entire EU.

Nature conservation management, silvicultural practice and public perception concerning NNT differ significantly across Europe, as do the associated legal instruments and approaches that provide the frame for day-to-day management practice in forestry and nature conservation. A comprehensive study of the legal landscape relating to NNT is lacking - despite the fact that national legislation in particular should mirror national interests and therefore has a major impact on the future of NNT in Europe. In many European countries, certain NNT are being recognized as a threat, e.g. in the Norwegian Black List (Gederaas et al., 2012), while other countries have not yet engaged with this issue.

Therefore, the aims of this study are (1) to provide a comprehensive report on the landscape of European legal instruments concerning NNT, including the production of a comprehensive law reference table; (2) to analyse the respective regulatory intensity and legal approaches to dealing with NNT in each country and (3) to discuss differences and similarities in NNT legislation at the national and sub-national levels and the implications of differing approaches across Europe. To our knowledge, this is the first study of this kind. Especially with regard to the future challenges posed by biological invasions, climate change and high resource demand for timber, knowledge on the legislative landscape concerning NNT will be indispensable for the discussion of options for joint European strategies. 


\section{Material and methods}

In order to analyse the legislative approaches regulating nonnative tree species in Europe, we investigated valid national and subnational (regional and provincial, hereafter referred to as 'regional') legal instruments of all states on the European continent, including Turkey and Russia but excluding European microstates. Experts in each country helped us to obtain information on the legal and practical situations in the respective country using a targeted questionnaire. In addition to hard laws (legally binding instruments), we collected information on national forest strategies and similar soft laws (instruments lacking binding force, but producing significant practical effects) (Thürer, 2000) that are mandatory in certain cases (e.g. for state forests) and thus have practical implications on the use of NNT in forestry. For this second category, we collectively used the term 'effective soft laws'. An effective soft law, for example, maybe a forest management guideline for state forests or a national policy (plan) that is not mandatory directly, but becomes effectively compulsory where forest management plans (FMPs) that are accepted by a state authority are mandatory and where the FMPs will not be accepted if they do not comply with the national policy.

This data collection helped to update and expand information on legal restrictions for NNT that is already available in the Country Reports compiled in COST Action FP1403 (NNEXT) - Non-native tree species for European forests: experiences, risks and opportunities (Hasenauer et al., 2017). The NNEXT Country Reports are a compilation of questions and answers for 34 European and two neighbouring countries, and one question per country deals with legal restrictions on NNT.

This country-specific overview was our basis for designing a new questionnaire that was subsequently sent to the European country representatives of COST Action NNEXT, mainly scientists from the forestry and nature conservation sectors. They were invited to consult additional experts to ensure the questionnaire was complete. The questionnaire featured general questions on the forest situation in the respective country as well as detailed questions on hard law instruments, i.e. forest legislation and nature conservation acts dealing with NNT. Furthermore, questions on relevant soft law instruments including guidelines, black lists of non-native species that shall/must not be introduced or planted and certifications were also included. Every relevant hard or soft law reported by the respondents had to be provided as a soft copy or in the form of a link to the country's online legislation information system.

Because NNEXT did not cover all European countries, we independently investigated the legislative situation in six countries (Albania, Belarus, Iceland, Luxembourg, Moldova and Russia). We searched online legislative and policy databases for relevant legislation, i.e. FAOLEX database of FAO (FAO, 2019) and ECOLEX database operated by FAO, IUCN and UNEP specifically on environmental law (IUCN, 2019), and we also used these databases to complete information for NNEXT countries. Because FAOLEX and ECOLEX are not always up-to-date and may not include the latest amendments, we also consulted each country's official online legislation platforms. The online translation tools DeepL and Google Translate (DeepL GmbH, 2017; Google LLC, 2016) were used to translate legislative texts into English. All valid hard and effective soft laws that were considered relevant for this study and were in force in June/July 2019 were included in a law reference table (Supplementary material 1, Table S1). This law reference table also includes the weblinks to the official online legislation platforms.

Based on all identified relevant legal instruments, we developed five primary legislation indicators ('B - General ban', 'N - NNT Pool', 'A - Approval', 'E - Exclusion' and 'R - Requirements'; Table 1) that should provide a logical system of descriptors on which, how, where and under which requirements NNT are allowed/prohibited in a certain country or region (hereinafter collectively referred to as 'legal units'). In addition, a synthesis indicator on the 'Intensity' of legal restrictions on the practical use of NNT in forestry (Intensity I-V) was created (Table 2) and this is described later. The five primary legislation indicators and their categories were developed in an iterative process. First, we conceptualized an initial system of clearly distinguishable indicators and categories and tried to assign the countries and regions to these predefined indicators and categories. Indicators and categories had to be repeatedly adjusted when trying to assign a new legal entity, until eventually all cases were assigned. To avoid single-entry categories for rare cases, we used an 'Other' category. Certain exceptions/restrictions related to any selected category were also allowed, also to ensure no single-entry categories. For such exceptions and the category 'Other', special explanation was provided (Table 3 in Supplementary materials 2 to 6). Except for 'B' and in part for ' $N$ ', several categories per indicator were selected.

Legislation indicator 'B - General ban' covers cases where non-native species (in general, not only NNT!) are banned from or need permission for import, introduction into the wild or cultivation. This general ban, however, may be complemented by an explicit exemption from the ban for forestry or forest trees.

Legislation indicator ' $\mathrm{N}$ - NNT Pool' deals with the question of which NNT may be used in forestry; it constitutes the species pool, so to say, out of which the forester may chose the NNT to plant or to suggest in an FMP (see indicator ' $A$ '). Further restrictions concerning the area or cases where these NNT can be planted may apply (see indicators 'E' and 'R'). Categories 'N2', 'N3' and 'N8' can be chosen in addition to other ' $N$ '-categories.

Legislation indicator 'A - Approval' describes different mandatory approval mechanisms through which the planting of NNT must be approved by the authorities; this includes the approval of a FMP ('A1'), a reforestation plan ('A2'), an afforestation plan ('A3'), the obligation to receive approval specifically for every single plantation of NNT (which mostly comes along with the requirement of a risk assessment for the planned introduction) ('A4') and other special approvals (for planting other NNT than the generally allowed ones, or in certain otherwise prohibited areas or cases) ('A5'). The approval mechanisms A1-A3 may be generally mandatory, or may be mandatory only on state land, or for private forests (sometimes if the property or the single continuous forest area is larger than a certain minimum area), or in protected areas, or for certain NNT.

Legislation indicator ' $\mathrm{E}$ - Exclusion' highlights a large variety of areas or cases where NNT are not permitted to be used or where they need an approval (relates to A5), e.g. in Natura 2000 
Table 1 Five primary legislation indicators and categories describing the legislative approaches in regulating NNT, the number of countries and regions assigned to a certain category and the number of countries and regions that passed their own legislation that led to the categorization.

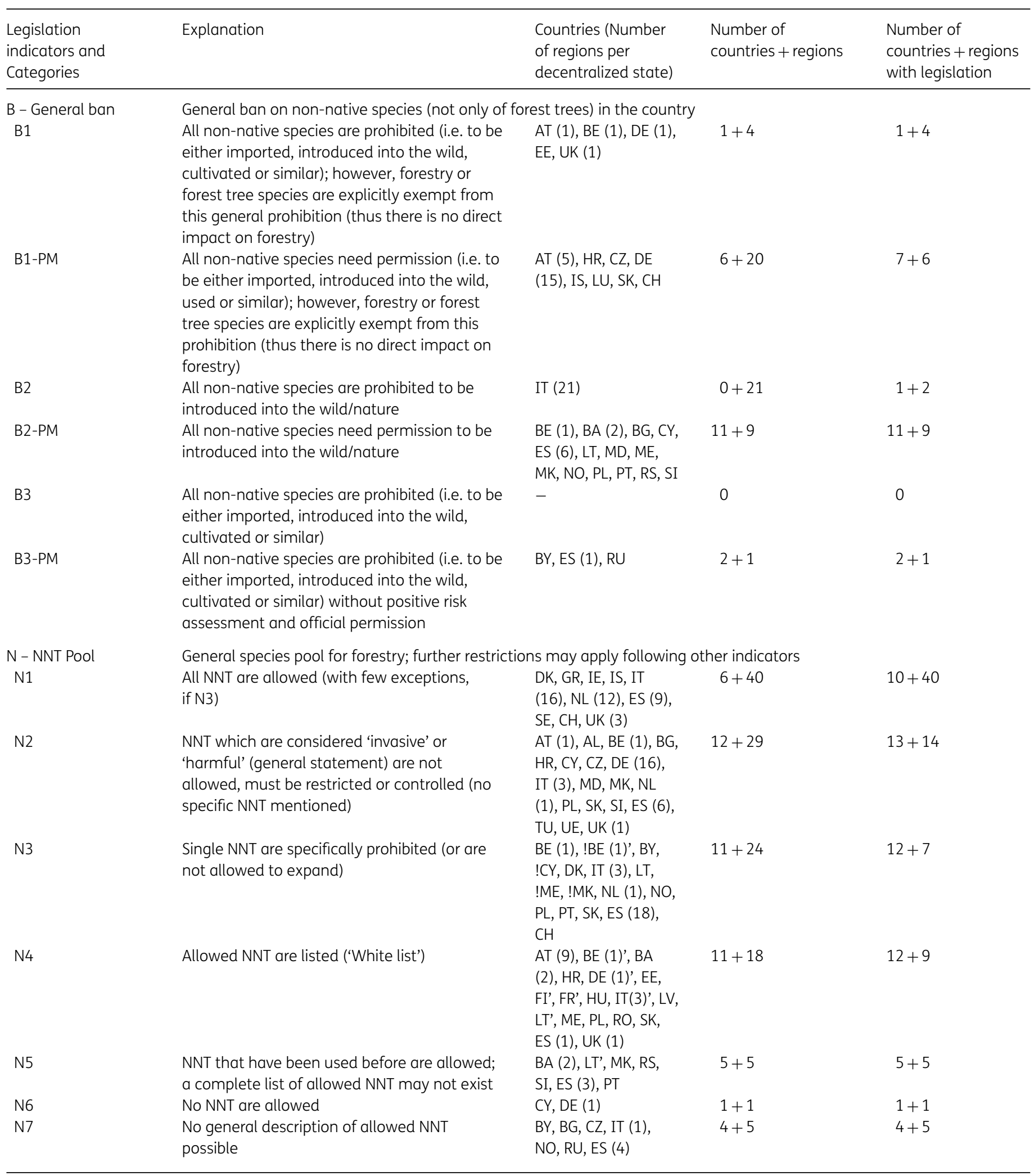


Table 1 Continue

\begin{tabular}{|c|c|c|c|c|}
\hline $\begin{array}{l}\text { Legislation } \\
\text { indicators and } \\
\text { Categories }\end{array}$ & Explanation & $\begin{array}{l}\text { Countries (Number } \\
\text { of regions per } \\
\text { decentralized state) }\end{array}$ & $\begin{array}{l}\text { Number of } \\
\text { countries + regions }\end{array}$ & $\begin{array}{l}\text { Number of } \\
\text { countries + regions } \\
\text { with legislation }\end{array}$ \\
\hline N8 & $\begin{array}{l}\text { New NNT can receive admission in the country } \\
\text { through a specified procedure, typically } \\
\text { including a risk assessment }\end{array}$ & $\begin{array}{l}\mathrm{BA}(2), \mathrm{HR}, \mathrm{IT}(1), \mathrm{LT} \\
\mathrm{MK}, \mathrm{NO}, \mathrm{PT}, \mathrm{RO}, \mathrm{RS} \\
\text { UK (1) }\end{array}$ & $7+4$ & $7+4$ \\
\hline A - Approval & Mandatory approval mechanisms in forestry & & & \\
\hline A1 & FMP & $\begin{array}{l}\text { AL, BE (2)', BY, BA } \\
\text { (2), BG, HR, CY', CZ', } \\
\text { DE (12)', EE, FR', GR', } \\
\text { HU, IE', IT (21)', LV', } \\
\text { LT, LU', MD, ME, MK, } \\
\text { PL, PT, RO, RU, RS, } \\
\text { SK, SI, ES (10)', TU, } \\
\text { UE, UK (4)' }\end{array}$ & $26+51$ & $29+26$ \\
\hline A2 & Reforestation/regeneration plan & $\begin{array}{l}\text { BY, BA (1), BG, FI, } \\
\text { HU, NL (10), PT, RU, } \\
\text { ES (6)' }\end{array}$ & $6+17$ & $6+17$ \\
\hline A3 & $\begin{array}{l}\text { Primary afforestation plan (for plantations on } \\
\text { previously non-forested land) }\end{array}$ & $\begin{array}{l}\text { BE (1), BY', BG, DE } \\
(13), I E, I S, L V, M D \\
\text { PT, RU, SK, ES (4)', } \\
\text { TU, UK (4)' }\end{array}$ & $10+22$ & $11+18$ \\
\hline A4 & $\begin{array}{l}\text { Approval specifically for every NNT plantation, } \\
\text { typically requiring a risk assessment }\end{array}$ & $\begin{array}{l}\text { BY, BG, CZ, MK, NO, } \\
\text { PT', RU, ES (4)', SE }\end{array}$ & $8+4$ & $8+4$ \\
\hline A5 & $\begin{array}{l}\text { Special approval required for the use of NNT in } \\
\text { specific areas or cases, where the use of NNT } \\
\text { otherwise would be prohibited (may relate to } \\
\text { 'E - Exclusion' with suffix '-A') }\end{array}$ & $\begin{array}{l}\text { BE (2), HR, LV, IT (1), } \\
\text { ME, MK, NL (1), PL, } \\
\text { RS, SI, ES (2), SE }\end{array}$ & $8+6$ & 6 \\
\hline E - Exclusion & \multicolumn{4}{|c|}{ Exclusion areas or cases where NNT are banned or need approval (see category A5) } \\
\hline E1 & Protected areas & $\begin{array}{l}\text { BE (2)', BY, CY, CZ, } \\
\text { DK', HU, IT (21), ME', } \\
\text { PL, PT', RS, SI, ES } \\
\text { (16), SE', CH, UE }\end{array}$ & $13+39$ & $15+14$ \\
\hline E1-A & ... without approval & ES (2) & $0+2$ & $0+2$ \\
\hline E2 & $\begin{array}{l}\text { Specific forest types or ecological regions (e.g. } \\
\text { mountain areas) }\end{array}$ & $\begin{array}{l}\mathrm{BE}(1), \mathrm{BG}, \mathrm{FR}, \mathrm{DE}(1) \\
\mathrm{LV}, \mathrm{ES}(1)\end{array}$ & $3+3$ & $3+3$ \\
\hline E2-A & ... without approval & AT (1), BE (1), SE & $1+2$ & $1+2$ \\
\hline E3 & Natural/native species forests & $\begin{array}{l}\text { BE (2)', HR, CY, DE } \\
\text { (2), FI, HU', IS, IT } \\
\text { (21), PL, RO, RS, SK, } \\
\text { ES (5), TU', UK (4) }\end{array}$ & $10+34$ & $12+12$ \\
\hline E3-A & ... without approval & NL (1)' & $0+1$ & $0+1$ \\
\hline E4 & $\begin{array}{l}\text { Other specified areas (e.g. certain distance to } \\
\text { a river) }\end{array}$ & $\begin{array}{l}\text { AT (1), BE (2), HU, IT } \\
\text { (1), LT, PT, ES (18), } \\
\text { SE, CH, UK (4) }\end{array}$ & $5+26$ & $7+7$ \\
\hline E4-A & ... without approval & - & 0 & 0 \\
\hline E5 & $\begin{array}{l}\text { Everywhere except at specified plantation } \\
\text { sites or sites currently stocked with NNT }\end{array}$ & CY, PL, PT', SK, ES (1) & $4+1$ & $4+1$ \\
\hline E5-A & ... without approval & $\mathrm{BE}(1)$ & $0+1$ & $0+1$ \\
\hline E6 & Other & $\begin{array}{l}\text { BE (1), DK, FR, IT (6), } \\
\text { LU, ES (2) }\end{array}$ & $3+9$ & $3+9$ \\
\hline
\end{tabular}


Table 1 Continue

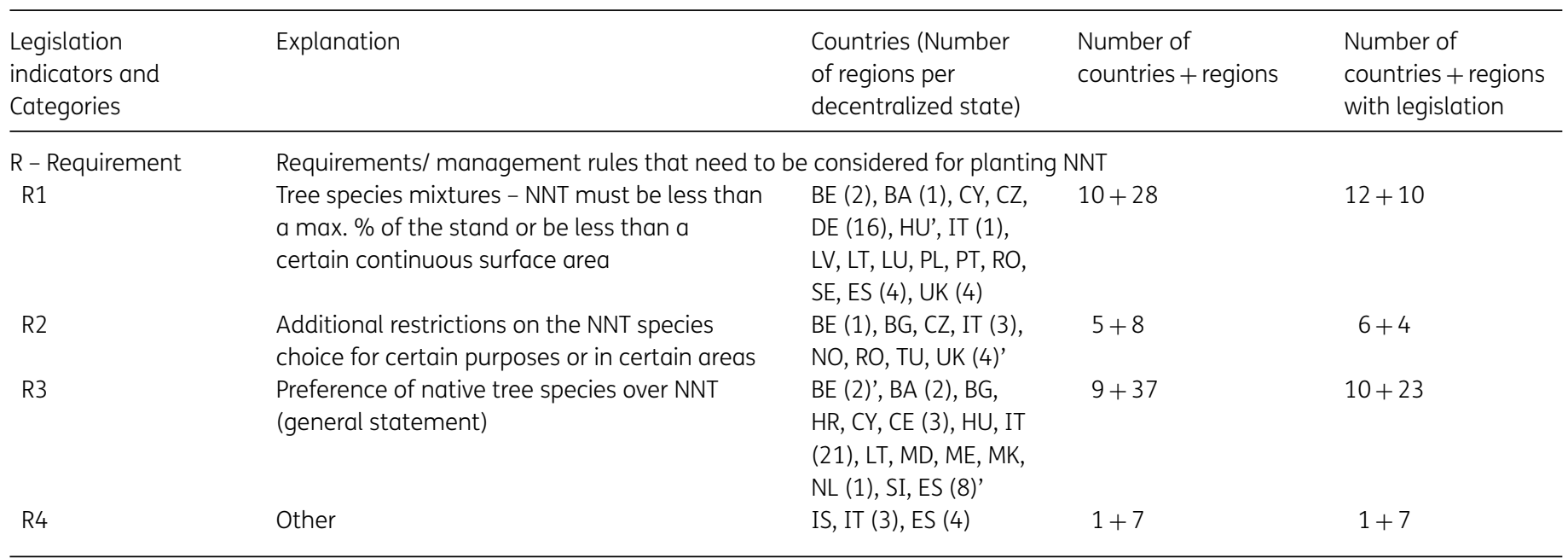

The decentralized states AT, BE, BA, DE, IT, NL, ES and UK are counted at regional level only. For indicators ' $A$ ' and 'R', cases where an approval is only needed to be eligible for subsidies or in protected areas are not listed; however, such cases can be found in Supplementary materials 4 and 6 . ' marks countries where the selected category does not apply entirely (e.g. because it only applies for state forests). Details on these limitations are given in Supplementary materials 2 to 6 . ! indicates that the assignment is based on an effective soft law.

Table 2 Synthesis legislation indicator 'Intensity' describing the overall intensity of restrictions on the use of NNT in forestry and the selection criteria based on the five primary legislation indicators (Table 1).

\begin{tabular}{llc}
\hline Intensity & Selection criteria & Number of assigned countries + regions \\
\hline I - Low & Any category of the five primary indicators & $5+11$ \\
& that is none of the categories below & $5+35$ \\
II - Moderate & N4; E1; E2; E4; R1 ( $\geq 50 \%)$ & $14+32$ \\
III - Considerable & A1/A2 + R3; E3; R1 (20-50\%) & $7+5$ \\
IV - Severe & B3-PM; A4; E5; R1 (<20\%) & $1+1$ \\
V - Very severe & B3; N6 & \\
\hline
\end{tabular}

A legal unit is assigned to the most severe 'Intensity' level that applies.

sites or other protected areas ('E1'), in specific vegetation types or ecological regions ('E2'), in all native species forests ('E3'), in other specified areas or cases ('E4', 'E6') or in any area except those where NNT are already occurring or which are specifically designated for planting NNT ('E5') - latter certainly being the most far-reaching exclusion among these categories.

Legislation indicator ' $\mathrm{R}$ - Requirements' is forest management oriented and describes rules that a forester needs to consider when planting NNT. It involves the requirement for tree species mixtures ('R1'), additional restrictions on the NNT species choice for certain purposes or in certain areas ('R2'), the expressed preference of native tree species over NNT ('R3') or other ('R4').

As a synthesis of the five primary legislation indicators (Table 1), we developed a five level classification scheme on the overall 'Intensity' of legal restrictions on the practical use of NNT in forestry (Intensity I-V, Table 2). A legal entity is assigned to the most severe 'Intensity' level that applies. The rationales behind the classification scheme are as follows.

1. Intensity 'I - low': By and large, it is the free choice of the forest owner where and what to plant, even though 'invasive' or 'harmful' species - as a general statement - may be prohibited (N2) or certain 'invasive' species may be prohibited (N3).

2. Intensity 'II - moderate': The reasons to choose this category are manifold - N4; E1; E2; E4 or R1 ( $\geq 50$ per cent) - but overall, the restrictions are not very far reaching, neither considering the choice of the species nor the area where to plant NNT. Although the share of NNT in a forest stand may be restricted, NNT are allowed to be the dominant species in a stand - R1 (>50 per cent).

3. Intensity 'III - considerable': The range of effective restrictions is potentially large and cannot be entirely determined from legislation. A mandatory FMP or reforestation plan in combination with the rule that native tree species should be preferred over non-native tree species $(\mathrm{A} 1 / \mathrm{A} 2+\mathrm{R} 3)$ can potentially lead to serious restrictions. The administration who is responsible for the approval or the preparation of the FMP may, for example, prescribe a higher share of native species than that proposed or anticipated by the forest owner or certain/all NNT may not be approved at all. The prohibition against replacing natural forests or native tree species (E3) may exclude a substantial or a minor area from the use of 
Table 3 Studied countries, regions and the assigned 'Intensity' category

\begin{tabular}{|c|c|c|}
\hline Country & Region & Intensity \\
\hline Albania - AL & - & I \\
\hline Austria - AT & - & II \\
\hline Austria - AT & Burgenland - BU & II \\
\hline Austria - AT & Kärnten - KA & II \\
\hline Austria - AT & Niederösterreich - NO & II \\
\hline Austria - AT & Oberösterreich - OO & II \\
\hline Austria - AT & Salzburg - SZ & II \\
\hline Austria - AT & Steiermark - ST & II \\
\hline Austria - AT & Tirol - TR & II \\
\hline Austria - AT & Vorarlberg - VO & II \\
\hline Austria - AT & Wien - WI & II \\
\hline Belarus - BY & - & IV \\
\hline Belgium - BE & - & - \\
\hline Belgium - BE & Vlaanderen - VL & IV \\
\hline Belgium - BE & Wallonie - WL & III \\
\hline Bosnia and Herzegovina - BA & - & - \\
\hline Bosnia and Herzegovina - BA & Federacija Bosna i Hercegovina - BF & III \\
\hline Bosnia and Herzegovina - BA & Republic of Srpska - SR & III \\
\hline Bulgaria - BG & - & IV \\
\hline Croatia - HR & - & III \\
\hline Cyprus - CY & - & V \\
\hline Czech Republic - CZ & - & IV \\
\hline Denmark - DK & - & I \\
\hline Estonia - EE & - & II \\
\hline Finland - FI & - & III \\
\hline France - FR & - & II \\
\hline Germany - DE & - & II \\
\hline Germany - DE & Baden-Württemberg - BW & II \\
\hline Germany - DE & Bayern - BY & II \\
\hline Germany - DE & Berlin - BE & V \\
\hline Germany - DE & Brandenburg - BR & III \\
\hline Germany - DE & Bremen - HB & II \\
\hline Germany - DE & Hamburg - HH & II \\
\hline Germany - DE & Hessen - HE & II \\
\hline Germany - DE & Mecklenburg-Vorpommern - MV & II \\
\hline Germany - DE & Niedersachsen - NI & II \\
\hline Germany - DE & Nordrhein-Westfalen - NW & II \\
\hline Germany - DE & Rheinland-Pfalz - RP & II \\
\hline Germany - DE & Saarland - SL & III \\
\hline Germany - DE & Sachsen - SN & II \\
\hline Germany - DE & Sachsen-Anhalt - ST & II \\
\hline Germany - DE & Schleswig-Holstein - SH & II \\
\hline Germany - DE & Thüringen - TH & III \\
\hline Greece - GR & - & I \\
\hline Hungary - HU & - & III \\
\hline Ireland - IE & - & I \\
\hline Iceland - IS & - & III \\
\hline Italy - IT & - & III \\
\hline Italy -- IT & Abruzzo - AB & III \\
\hline Italy -- IT & Apulia - AP & III \\
\hline Italy -- IT & Basilicata - BS & III \\
\hline Italy -- IT & Calabria-CL & III \\
\hline Italy -- IT & Campania-CM & III \\
\hline
\end{tabular}


Table 3 Continue

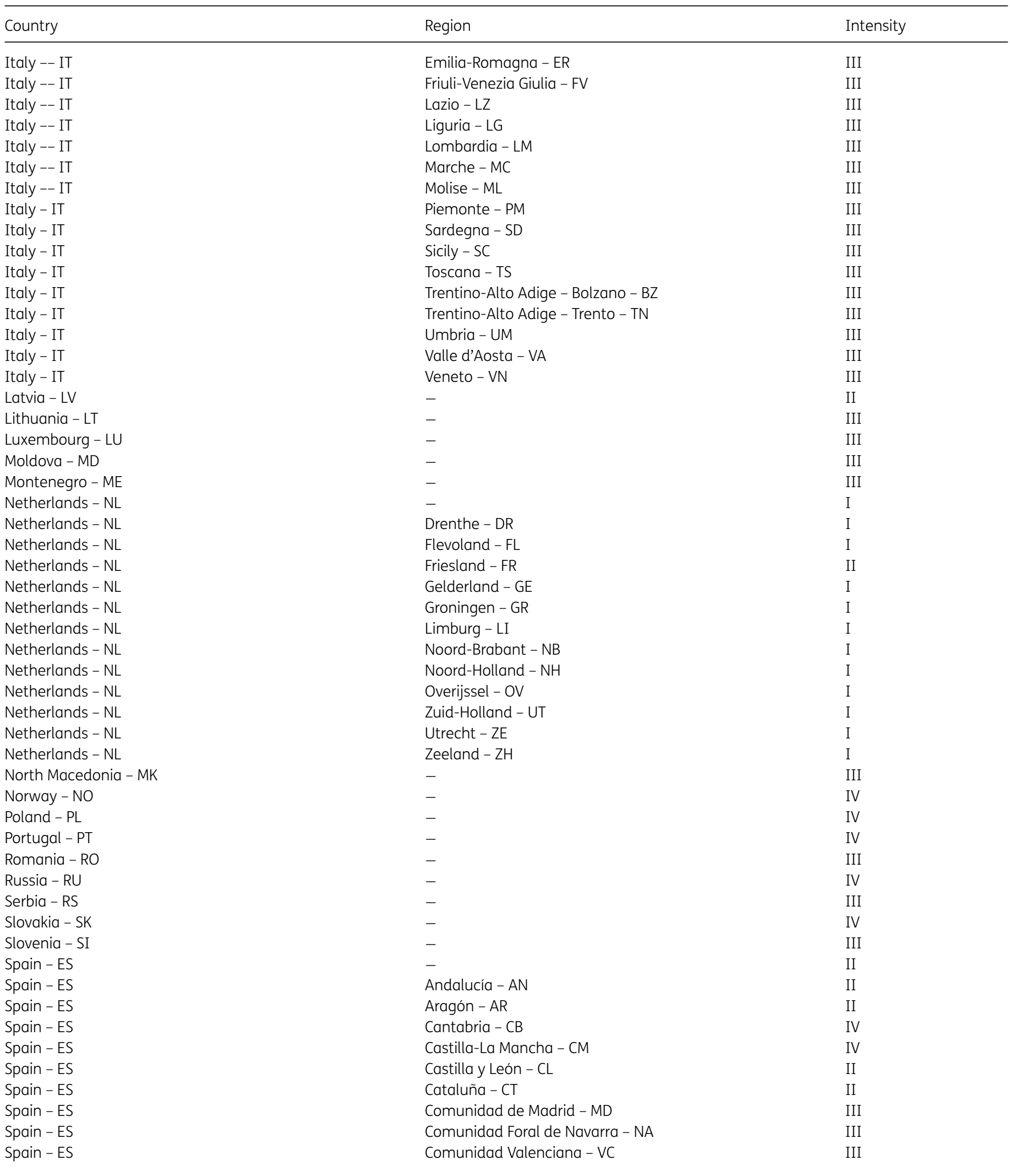


Table 3 Continue

\begin{tabular}{lll}
\hline Country & Region & Intensity \\
\hline Spain - ES & Extremadura - EX & IV \\
Spain - ES & Galicia - GA & IV \\
Spain - ES & Islas Baleares - PM & II \\
Spain - ES & La Rioja - LO & III \\
Spain - ES & País Vasco - Álava - AA & II \\
Spain - ES & País Vasco - Guipúzcoa - GP & II \\
Spain - ES & País Vasco - Vizcaya - VZ & II \\
Spain - ES & Principado de Asturias - AS & III \\
Spain - ES & Región de Murcia - MU & II \\
Sweden - SE & - & III \\
Switzerland - CH & - & II \\
Turkey - TU & - & II \\
Ukraine - UE & - & I \\
United Kingdom - UK & - & II \\
United Kingdom - UK & England - EG & II \\
United Kingdom - UK & Northern Ireland - NI & II \\
United Kingdom - UK & Scotland - SC & II \\
United Kingdom - UK & Wales - WL & II
\end{tabular}

NNT, depending on the current state of forest naturalness in the country. Also, NNT may not be allowed to be the dominant species in a stand - R1 (20-50 per cent).

4. Intensity 'IV - severe' follows category A4, which indicates countries and regions where every NNT plantation needs special approval, mostly involving individual risk assessment. It also follows E5, which limits the use of NNT to areas where NNT do already grow or which are designated by the authorities for exceptionally planting NNT. Also countries and regions where NNT are only allowed to have a minor share in the tree species cover of a stand are selected - R1 (<20 per cent).

5. Intensity ' $\mathrm{V}$ - very severe' is selected for the two strictest categories of legislation indicators B - General ban and N NNT Pool, i.e. B3 and N6, both of which imply a complete or almost complete ban of NNT in forestry.

In cases where one of the relevant primary categories would only apply to a considerably limited extent, the lower intensity level was selected. An example would be a legal entity that is categorized as E5(|) (E5 with suffix (|) what means 'with exceptions/restrictions'), which would normally lead to 'Intensity IV' but instead is classified as 'III' because the restriction of not expanding the area of plantations only concerns Eucalyptus spp. It also should be considered that because the classification scheme also considers the expert interpretation of the severity of restrictions imposed by the authorities, the classification scheme has an element of subjectivity.

Ten of the investigated countries are federal states or other highly decentralized states with concurrent regional legislation (Austria, Belgium, Bosnia and Herzegovina, Germany, Italy, the Netherlands, Russia, Spain, Switzerland and the UK, hereafter called 'decentralized states'). In these countries, certain competences relevant to the regulation of NNT may lie exclusively with the national or regional level of administration, or with both levels. States may delegate certain competences to the regional level by way of national law. Six of these 10 countries were thus categorized at both the national and regional levels. Due to the limited practical relevance of the mere national-level evaluation, results for these six states are primarily reported at the regional level. Russia and Switzerland were treated only at the national level because it was not possible to obtain the full necessary regional information. Belgium as well as Bosnia and Herzegovina, on the other hand, was categorized only at the regional level because no relevant national legal instruments could be identified. For two autonomous regions, legislation is delegated to an even lower hierarchical level (Basque Country - ES - three sub-regions, and Trentino-Alto Adige - IT - two sub-regions). In these cases, we performed our analysis at the corresponding subregional level. Regions geographically disconnected from Europe were not considered, i.e. the Azores, Madeira, the Canary Islands, Ceuta and Melilla. The Federation of Bosnia and Herzegovina (FBiH, one of the legislative units of the country Bosnia and Herzegovina) is composed of 10 cantons with cantonal forest legislation. FBiH declared its forest law unconstitutional in 2009, and the 10 cantons subsequently adopted their own forest laws. These cantonal forest laws are very similar to the former $\mathrm{FBiH}$ forest law (in terms of their relevance for this study, according to expert information). For this reason, we only evaluated the $\mathrm{FBiH}$ regional forest law despite the fact that it is currently ineffective. France, an overall centralized state but consisting of administrative regions with local governments, gives some limited budget authority to its 13 metropolitan regions. Due to the limited legislative authority of the regions, we decided to evaluate and categorize France as an entity, although several regional orders on subsidies have regionally differing effects on the planting of NNT.

In total, over 60 experts from 34 countries responded to the questionnaire, helped us with the interpretation of legislation and the practical situation in their countries and contributed to 
the development of the legislation indicators and categories and verified the categorization (all major contributors are co-authors of this study).

\section{Results}

We identified and analysed hard and soft law relevant for the use of NNT in forestry in 40 European countries. In total, 116 legal units (countries and regions) were analysed and categorized (122 legal entities if also counting the national level evaluation of decentralized states which otherwise were only investigated at regional level). We reviewed several 100 legislative acts and identified 335 national and regional hard and effective soft law instruments relevant for the regulation of NNT in Europe (Supplementary material 1).

An overview of the resulting classification using the five primary indicators is shown in Table 1 , and the results of the synthesis assessment 'Intensity' are shown in Tables 2 and 3. The detailed results on the primary indicators are given in Supplementary materials 2 to 6 , together with the specific laws and the paragraphs, on which the selection of a category was based on. Together with the law reference table (Supplementary material 1), this approach allows for tracing back the original text in the legislation and yields an unprecedented database on NNT legislation across Europe.

Legislation indicator 'B - General ban' was found in force 75 times (Table 1). All but two of the legal instruments that demanded a General ban are nature conservation legislations, including five acts specifically on non-native species. Only for two regions the ban regulated through a forestry law (Friuli-Venezia Giulia (IT) and Flanders (BE; only state forests). A map of all legal units with a General ban is shown in Figure 1, and detailed results are given in Supplementary material 2.

The results for legislation indicator ' $N$ - NNT Pool' show that in 46 countries or regions (or 40 per cent of the 116 investigated legal units), no general prohibition on the choice of the tree species is in place ('N1'). In 41 legal units (35 per cent of all legal units), it is generally stated that no 'invasive' or 'harmful' NNT are allowed, 27 of which do not specifically ban any NNT. On the other hand, 19 legal units have enacted a legal instrument to prohibit the use of a specific NNT or to restrict its expansion and eradicate it locally ('N3'). Hard law is responsible for 15 of these bans, while effective soft law prohibits NNT in four legal units. Such ban of certain NNT applies to 35 (30 per cent) of the 116 investigated countries and regions. In total, 24 tree species and two genus groups (Acacia spp. and Eucalyptus spp.) are prohibited to be used for reforestation and afforestation in one or more legal units (Table 4). Tree of heaven is the most widely banned species, with 11 legal units prohibiting its use, followed by box elder and black locust with nine bans each. Importantly, we did not include any changes in national or regional legislations following the last update of the Union list that now includes tree of heaven and Port Jackson wattle. In 29 legal units, a so-called white list exists, a list of NNT allowed for forestry ('N4'). For 10 countries and regions, the situation can be best described as 'NNT that have been used before are allowed' ('N5'). One country (CY) and one region (Berlin - DE) prohibit the use of all NNT in forestry ('N6'). For nine countries and regions, it is not feasible to specify whether some, all or no NNT are generally allowed ('N7'), in seven cases because every single plantation of NNT has to undergo a specific approval procedure, for which a risk assessment for the specific case is required, and in two cases because of other reasons. Furthermore, 11 legal units describe, in more or less detail, a procedure that allows a previously not allowed NNT to be incorporated into the generally allowed NNT pool (in the meaning of this legislative indicator as described above) ('N8'). Most of these procedures also involve a certain level of risk assessment. Detailed results are given in Supplementary material 3.

The investigation of approval mechanisms revealed that the vast majority of legal units (100 out of 116) use at least one of the approval mechanisms considered by legislation indicator 'A - Approval'. An overview of the legal units prescribing one or several of these approval schemes is given in Figure 2 and Table 1. Detailed results are given in Supplementary material 4.

Legislation indicator 'E - Exclusion' shows that in 45 per cent of the investigated legal units NNT are explicitly prohibited in protected area ('E1') and in 38 per cent in natural/native species forests ('E3'). 27 per cent of legal units protected other specified areas from NNT ('E4'). More results are given in Table 1 and in Supplementary material 5.

According to legislation indicator 'R-Requirements', one-third of the investigated legal units restrict the share of NNT in a plantation or the surface area of NNT plantations ('R1'). In 40 per cent of the cases, the preference of native species over non-native species for the use in forestry is clearly expressed in the legislation. More results are given in Table 1 and in Supplementary material 6.

The synthesis legislation indicator 'Intensity' of legal restrictions on the practical use of NNT in forestry revealed that intensity of restriction can be classified as 'I - low' 16 times (14 per cent of all legal units, 'II - moderate' 40 times (34 per cent of all legal units), 'III - considerable' 46 times ( 40 per cent of all legal units), 'IV - severe' 12 times ( 10 per cent of all legal units) and ' $V$ - very severe' 2 times ( 2 per cent of all legal units). The results for each legal unit are shown in Table 3.

\section{Discussion}

This Europe-wide analysis of the legislation framework clearly shows that the use of non-native tree species in European countries is directly and indirectly affected by a plethora of legislative hard and effective soft law instruments. These legal instruments not only bring about a multitude of individual measures but also reveal more general approaches of regulating NNT. Measures may be applied differently in state forests, private forests and protected areas or differently for fast-growing vs other, less economically important NNT. Overall, NNT receive largely differing attention in the investigated countries and regions, ranging from basically no or very little restrictions on the species choice and surface area for plantations (AL, DK, GR, IE, NL, UE, intensity of restriction level I) to a complete ban of NNT in forests (Berlin DE and CY, intensity of restriction level V). Half of the over 100 investigated legal units, however, have considerable to severe restrictions in force (intensity of restriction levels III and IV, 


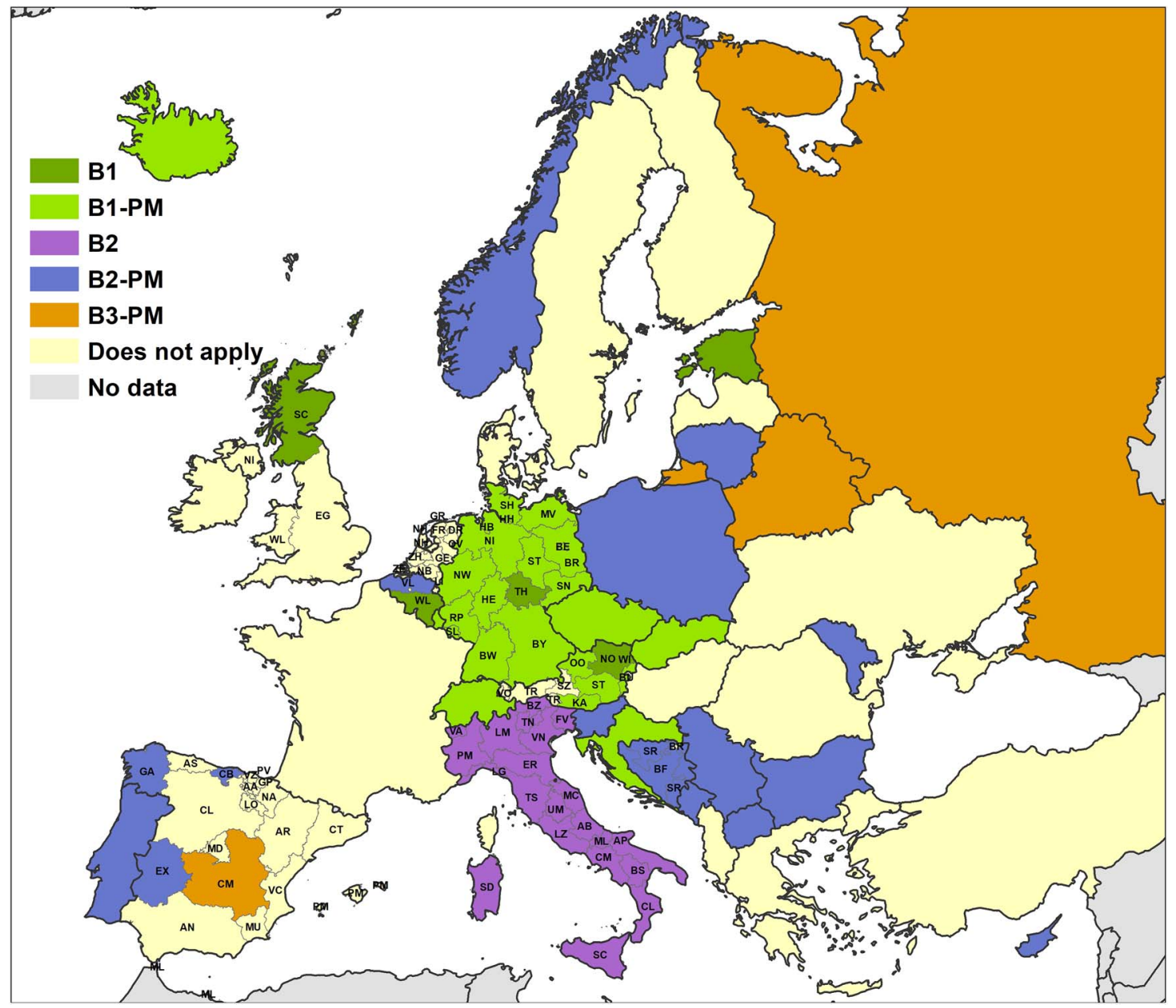

Figure 1 Map of investigated European countries and regions showing the classifications for legislation indicator 'B - General ban', which categorizes bans of non-native species in general. Categories according to Table 1. Disclaimer: Kosovo is mapped as part of Serbia - without any prejudice to the status of Kosovo.

compare Tables 2 and 3 and Figure 3). Our map of the synthesis indicator intensity of restrictions (Figure 3) provides an overview of the legislator's level of concern about using NNT in forestry. While it is obvious that the intensity of regulation does not allow for any conclusion on the actual interest of forest owners in planting NNT, also a high intensity of regulation does not necessarily come along with a low effective importance or area of NNT in a country. We can illustrate this by comparing Portugal and Slovakia. Both countries are categorized as E5 (NNT are only allowed on plantation sites or sites currently stocked with NNT), which demands Intensity IV (in fact, Portugal as a whole was classified III because the restriction on expanding plantation areas actually only applies to Eucalyptus spp.). However, the extent to which NNT can still be used in the country depends on the actual area of NNT at the time of coming into force of the regulation. In Slovakia, the share of NNT is rather low - around 3 per cent (Forest Europe, 2015a; Kormutak et al., 2017), whereas in Portugal Eucalyptus spp. is the most dominant tree species and makes up over 25 per cent of the forest area of continental Portugal (Tomé et al., 2017).

\section{Contrasting interests}

Legislative authorities face the continuous challenge in forestry and nature conservation legislation to balance their commitment to protect the environmental assets against the risk that a NNT might threaten biodiversity and native ecosystems and permit the benefits and opportunities that many NNT bring about (Schulz et al., 2014). This is a well-known dilemma, already described in detail e.g. for South Africa (van Wilgen and Richardson, 2014) and epitomized by the term 'controversial tree'. What is considered as the right balance between opportunity and risk may change considerably over time; and it depends on what is valued or perceived more crucial at a certain time - forest productivity, forest functioning, ecosystem service protection or minimizing invasion risk - and what are considered appropriate measures. The discussions and controversies around these questions are extensive on all levels of society, policy and science (Ammer et al., 2014; Forest Europe, 2015b; Derks, 2019).

Conflicts between biodiversity conservation and agricultural and forestry land uses are a very common phenomenon not only 
Table 4 Prohibited NNT and the number and name of countries where the NNT are prohibited (either in the entire country or in one or several provinces).

\begin{tabular}{|c|c|c|c|}
\hline Species & Common name & Legal units & $\begin{array}{l}\text { Number of } \\
\text { countries + regions }\end{array}$ \\
\hline Acacia spp. Mill. & Wattles & PT, ES-GA & $1+1$ \\
\hline Acacia dealbata Link & Silver wattle & ES & $1+0$ \\
\hline Acacia saligna (Labill.) H.L.Wendl. & Port Jackson wattle & !CY & $1+0$ \\
\hline Acer negundo L. & Box elder & $\begin{array}{l}\text { BY, IT-LM², IT-PM, LT, } \\
\text { !MK, !ME, NL-FL, PT, SK }\end{array}$ & $6+3$ \\
\hline Ailanthus altissima (Mill.) Swingle & Tree of heaven & $\begin{array}{l}\text { !BE-WL, !CY, IT-LM², } \\
\text { IT-PM, IT-TS, !MK, !ME, PL, } \\
\text { PT, SK, ES }\end{array}$ & $7+4$ \\
\hline Broussonetia papyrifera (L.) L’Hér. ex Vent. & Paper mulberry & IT-LM², IT-PM, !MK, !ME & $2+2$ \\
\hline Catalpa ovata G. Don & Yellow catalpa & IT-PM & $0+1$ \\
\hline $\begin{array}{l}\text { Catalpa speciosa (Warder ex Barney) } \\
\text { Warder ex Engelm. }\end{array}$ & Northern catalpa & IT-PM & $0+1$ \\
\hline Elaeagnus angustifolia L. & Russian olive & !MK & $1+0$ \\
\hline Eucalyptus spp. L'Hér. & Eucalypt & IT-TS & $0+1$ \\
\hline Gleditsia triacanthos L. & Honey locust & PT & $1+0$ \\
\hline Leucaena leucocephala (Lam.) de Wit & Horse tamarind & !CY, PT & $2+0$ \\
\hline Parkinsonia aculeata $\mathrm{L}$. & Mexican palo verde & !CY & $1+0$ \\
\hline Paulownia tomentosa (Thunb.) Steud. & Princess tree & IT-PM, PT & $1+1$ \\
\hline Pittosporum undulatum Vent. & Sweet pittosporum & PT & $1+0$ \\
\hline $\begin{array}{l}\text { Populus balsamifera L., P. x berolinensis } \\
\text { K.Koch }\end{array}$ & Balsam poplar, $P . \times$ berolinensis & $\mathrm{NO}^{1}$ & $1+0$ \\
\hline Prunus serotina Ehrh. & Black cherry & $\begin{array}{l}\text { BE-VL, !BE-WL, IT-LM², } \\
\text { IT-PM, LT, DK }\end{array}$ & $2+4$ \\
\hline Quercus rubra L. & Northern red oak & BE-VL, IT-LM², IT-PM & $0+3$ \\
\hline Robinia pseudoacacia L. & Black locust & 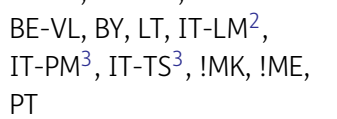 & $5+4$ \\
\hline Rhus typhina L. & Staghorn sumac & IT-PM, CH & $1+1$ \\
\hline Salix euxina I.V.Belyaeva, S. x fragilis L. & Crack willow & $\mathrm{NO}^{1}$ & $1+0$ \\
\hline Ulmus pumila $\mathrm{L}$. & Siberian elm & IT-PM & $0+1$ \\
\hline
\end{tabular}

The respective legal instruments can be found in Supplementary material 3, where category 'N3' applies. The state shown is the situation right before the updated of the EU list of invasive alien species of Union concern in July 2019. ! indicates that the ban is based on an effective soft law. ${ }^{1}$ From year 2021 on. ${ }^{2}$ Not allowed to expand, must be monitored and eradicate locally. ${ }^{3}$ Prohibited, but with exceptions (see Supplementary material 3).

in Europe (e.g. Young et al., 2010; Bateman et al., 2013; Pacheco et al., 2014; Riding et al., 2015) but also at the global scale (e.g. de Jong, 2002; Tscharntke et al., 2012; Zabel et al., 2019). The conflicts reflect a different vision and mission of these three sectors, with different authorities being in charge of legislative action and executive control and, often, with resulting conflicting legislation and terminology on non-native species.

When international legislation acts are taken into concern, one additional challenge arises - balancing the commitment to international obligations with the sovereignty in national or regional forest policy, such as the freedom to test, breed and plant those tree species or provenances that are expected to be most suitable in forestry. A particularly interesting finding was the differing implications of the Alpine Convention among signature countries. While France has introduced specific measures to limit the use of NNT in Alpine areas and only explicitly allows for few NNT in Southern Alpine regions (as a climate change adaptation measure), to our knowledge no other country has introduced restrictions on planting NNT in mountainous regions as a consequence of the Alpine Convention.

\section{Change over time}

While we did not collect information on the historic development of NNT legislation, a number of legislations can only be well understood if correctly placed in their respective historic and cultural context. Typically, early legislation was more liberal, allowing largely unregulated introduction and use of NNT, while later concerns about the unregulated use of NNT found their way into legislation, in particular after the ratification of the Convention on Biological Diversity (CBD) and the Habitats Directive of 1992. In Italy, for example, starting from the years after World War II, industrial plantations with NNT (e.g. Eucalyptus spp. and Pinus spp.) were frequently carried out in support of employment in rural and disadvantaged areas and to boost the industrial development (Pra et al., 2019). In 1997, however, Italy introduced 


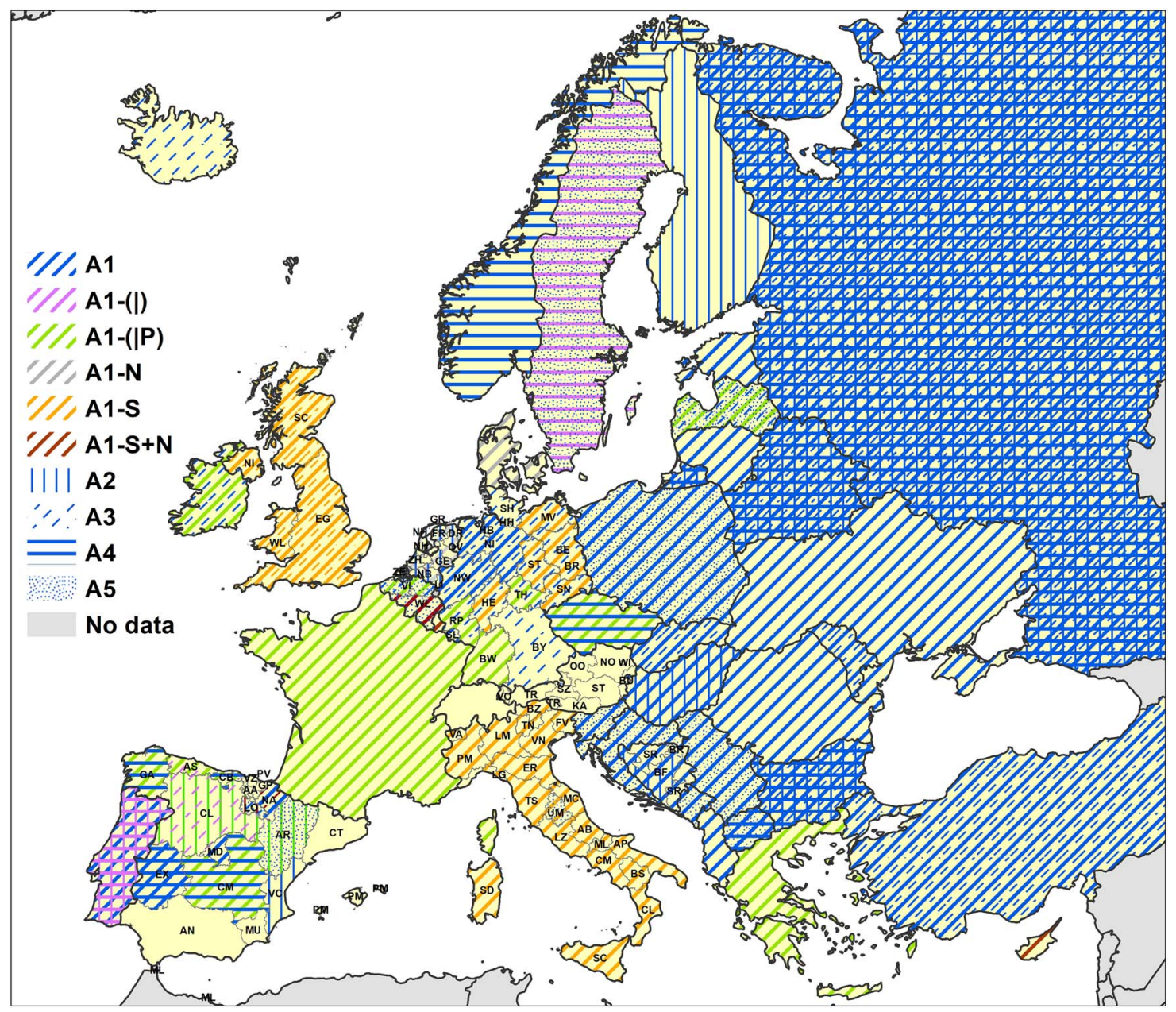

Figure 2 Map of investigated European countries and regions showing the approval requirements according to legislation indicator ' $\mathrm{A}-\mathrm{Approval}$ ' with categories according to Table 1 . Suffix $(\mid)$ - with exceptions, (|P) - with exceptions in private forests, $N$ - only in protected areas, $S$ - only in state forests; the colour code is based on the suffix and is identical for all categories (A1-A5). Cases where approvals are only needed to be eligible for state subsidies are not indicated in the map. Disclaimer: Kosovo is mapped as part of Serbia - without any prejudice to the status of Kosovo.

the general ban on the introduction of non-native species into the wild (B2) following the Habitats Directive, a ban which not only applies to Natura 2000 sites but in many regions is interpreted more strictly and applies to the whole natural environment (see following sub-chapter). More countries could be named where for economic reasons and for the reclamation of degraded areas, NNT were promoted throughout most of the $20^{\text {th }}$ century but restrictions became stronger over time (Nyssen et al., 2016; Hasenauer et al., 2017; Pötzelsberger, 2018). This phenomenon also explains why several countries were classified as N5 or E5 restricting either the species choice or the area of plantation to what is already present in the country. At the beginning of the 1990s, also EU-based subsidies promoted the use of a number of NNT in forest and in agroforestry systems, for afforestation and reforestation (through Council Regulation (EEC) No. 2080/92 of 30 June 1992 and by Regulation No. 2078/1992) (Santiago-Freijanes et al., 2018), measures accompanying the Common Agricultural Policy (CAP) or the later regional Rural Development Programs, co-financed by the European Agricultural Fund for Rural Development (Pra et al., 2019). After the ratification of the Convention on
Biological Diversity, there was a general commitment to mitigate the risks from biological invasions, reflected for example by the Second Ministerial Conference on the Protection of Forests in Europe (Forest Europe, 1993) or the Habitats Directive.

\section{Implications of the Habitats Directive and the Forest Europe process}

The Habitats Directive led to varying applications at the national and regional levels and with different interpretations of the Article 22.b, which calls for regulation of the 'deliberate introduction into the wild of any species which is not native to their territory'. A considerable number of legal units use a formulation in their nature conservation legislation that has strong similarities to that Article (30 among the 44 countries which introduced a General ban, see indicator B). Due to the vague wording of the Directive, the interpretation and implications differ among the countries. Countries may or may not consider managed or planted forests as 'the wild' or they may focus on the term 'introduction' and thus treat established NNT differently from NNT not yet present 


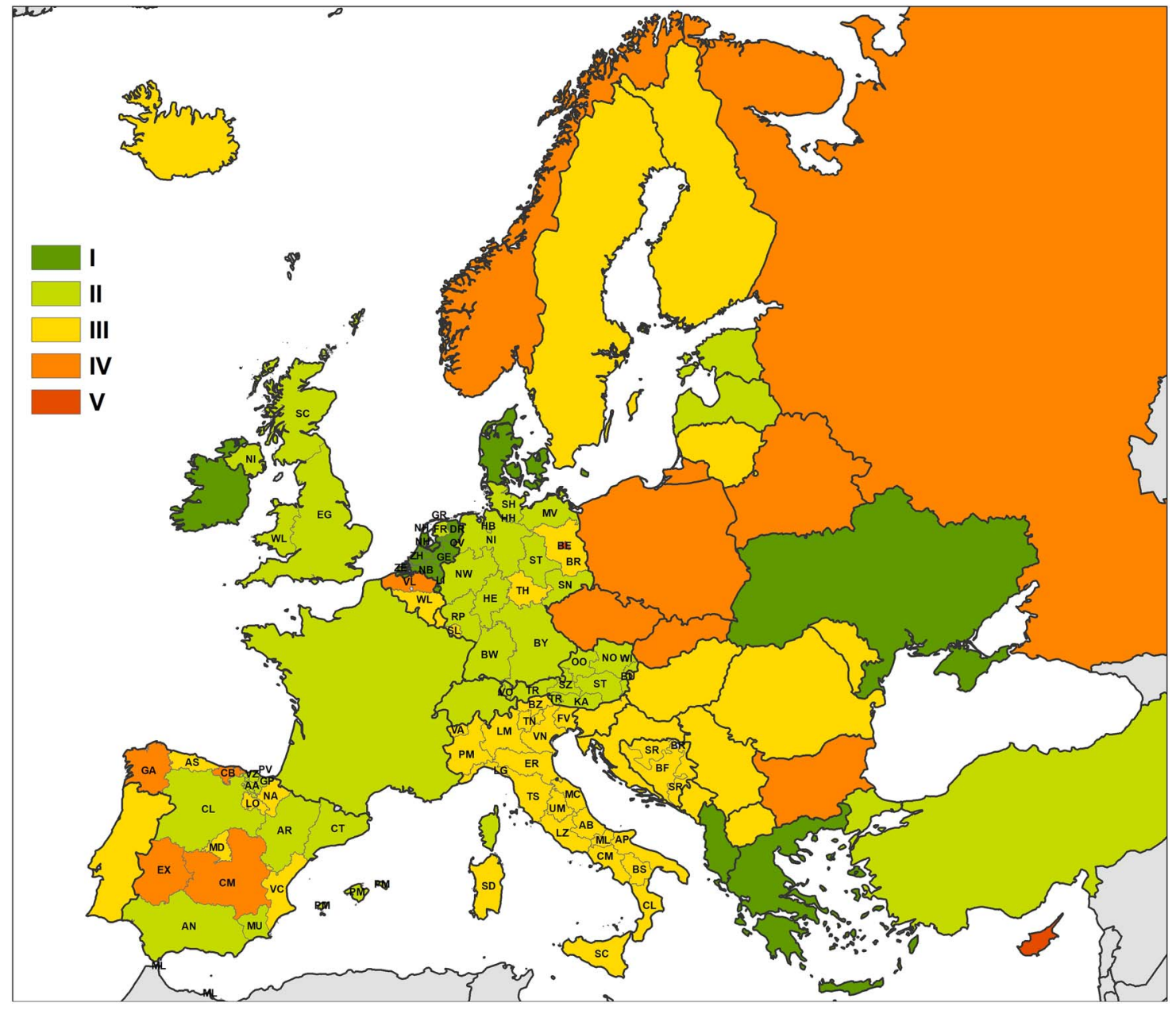

Figure 3 Map of investigated European countries and regions showing the five classes of 'Intensity' of restrictions as synthesis classification of the five primary legislation indicators. Classes I-V indicate low to very high level of restriction. Selection criteria are given in Table 1. Disclaimer: Kosovo is mapped as part of Serbia - without any prejudice to the status of Kosovo.

in the country or allow the use of NNT on areas where they have been planted earlier. In most countries where introduction into the wild' is prohibited without approval (B2-PM), forests are managed according to an FMP approved or prescribed by the forest authorities. Therefore, the permission for introduction may come through the approval of the FMP or through a more NNTspecific approval procedure where additional requirements may be in place, such as risk assessments (compare indicator A4).

There is a large overlap in countries which adopted the Habitats Directive's recommendation of regulating the 'deliberate introduction into the wild' and the Helsinki resolution's recommendation that 'Native species ... should be preferred ...' (R3) (Forest Europe, 1993). In total, this preference of native tree species has been adopted in 33 legal acts (Table 1), applying to 47 (over one third) of the investigated legal units. Almost all of these legal units prescribe some sort of approval mechanism for planting ( $\mathrm{A} 1, \mathrm{~A} 2$, or $\mathrm{A} 3$ ), which renders this recommendation very relevant. But it also introduces subjectivity and unpredictability because (local) forest authorities who approve an FMP decide whether or not to accept NNT for a certain plantation. Guidance may come through a national forest strategy or biodiversity strategy, which may be more specific on the species question or the extent to which certain or all NNT are supported. Policies, however, are regularly or occasionally updated (e.g. every 20 years in North Macedonia, MK1§23, or after $10-40$ years as in Cyprus, !CY2, Supplementary Table S1), what can have serious impacts on the forest management planning and the seedling production in nurseries.

In the Natura 2000 network, according to Article 6 of the Habitats Directive, it shall be avoided, 'the deterioration of natural habitats and the habitats of species as well as disturbance of the species for which the areas have been designated, in so far as such disturbance could be significant in relation to the objectives of this Directive.' Therefore, regulations directed at Natura 2000 can have large direct and indirect impacts on the use of NNT; and some countries and regions prohibit NNT in Natura 2000 sites by hard law while others introduce soft law restrictions. Whether and to which extent NNT are explicitly prohibited differs among countries, as does the area set aside for protection. Luxembourg, for example, protects $\sim 65$ per cent of the forest area under 
Natura 2000 regulation (Ministère de l'Environnement, 2016), according to which the destruction or deterioration of the habitats is prohibited (LU1§17, Supplementary Table S1). Bulgaria has set aside $\sim 60$ per cent of the forest area for Natura 2000 (Petkova et al., 2017) and explicitly prohibits NNT there (!BG2, !BG10, Supplementary Table S1). Germany protects various forest vegetation types (Fen and bog woodlands, riparian forests, forests of ravines, slopes and screes, subalpine larch forests and riparian larch forests, DE1§30, Supplementary Table S1), and four provinces protect additional forest vegetation types, but only one province specifically limits the share of NNT in these vegetation types (and thus was categorized as E2). EU Member States are, however, required to define indicators for the favourable conservation state of protected Natura 2000 habitats and this typically involves thresholds of permitted shares of NNT for three levels of conservation status (typically implemented through soft law instruments). Austria, for example, set the thresholds to 0 , 30 and 50 per cent habitat-foreign tree species (Ellmauer, 2005), while in Germany the provinces defined different levels of allowed NNT (Rosenkranz et al., 2012).

Also outside of protected areas, the share of NNT in a forest stand may be regulated (R1). About one-third of legal units apply such a restriction, which can be specific and rather soft, like in Principado de Asturias (ES) or UK, where at least 5 per cent of a plantation project must be native species. Or restrictions can be specific and strict, where no or few NNT can be the dominant species in a stand, like e.g. in Luxembourg or Thüringen (DE), where only one NNT (Douglas-fir) respectively two NNT (Douglasfir and Northern red oak) can cover more than 30 per cent respectively 20 per cent of a stand. The restriction can also be vague, like in Germany, where according to nature conservation legislation '...the aim must be to establish semi-natural forests and to manage these sustainably without clear felling. An adequate proportion of native woodland plants must be retained' (DE1§5, Supplementary Table S1). The vague wording probably serves the purpose to satisfy both the nature conservation side favouring native species and the forestry side demanding to retain the option to supplement the tree species choice with some useful NNT (Vor et al., 2015).

\section{The 'species question'}

Apart from the questions of where, how and how much NNT are allowed, the 'species question' is the primary one for all interested parties. Our study demonstrates, however, that neither the question of 'What trees are allowed?' nor the question of 'What NNT are prohibited?' is easy to answer, even without considering the additional uncertainty through mandatory approval mechanisms (A1, A2, A3). Especially for the 20 legal units that were categorized B2-PM ('non-native species need permission to be introduced into nature'), the sole interpretation of the legislation is inconclusive. With the help of the country experts, we found that for half of these B2-PM cases, the situation can in simple terms best be described as 'NNT that have been used before are allowed' (N5). These (and other) legal units may describe in varying detail a procedure for the admission of 'new' NNT to be generally allowed in the country that would typically include a risk assessment (N8). Despite our careful investigations, for a few legal units, it can simply not be stated whether all, some or no
NNT are generally allowed (categorized N7), because it depends on a strict approval requirement for every single NNT plantation, the outcome of which is unknown (A4).

One may expect that for allowed NNT the implementation of Council Directive 1999/105/EC on the marketing of forest reproductive material (FRM) plays a fundamental role for the species choice - especially the list of important native and nonnative forest tree species and artificial hybrids of Annex I to which the act applies (a list which the countries are allowed to modify when adopting the measures of the Directive). However, in most cases, this list does not constitute a list of 'allowed' species. We only found seven cases, where FRM acts were relevant for the question of which NNT are allowed. An example is Croatia, where the list of species determined by the FRM act (HR2) is exempt from the obligation to obtain a permit for the introduction of nonnative species into nature. Another example is Estonia, where only FRM produced within the country is permitted (EE3), which limits the potential species choice to the few species already present in Estonia.

In 41 legal units, the general statement to prohibit 'invasive' or 'harmful' species in forestry (N2) was introduced into legislation, while in 35 countries or regions an explicit ban of one or more NNT applies, explicitly banning 24 NNT in total (N3, Tables 1 and 4). Here, we may emphasize once more that we did not consider the vast number of black and grey lists with little or mostly no legal power, which exist in many European countries. The most widely banned NNT, tree of heaven, is banned in 11 legal instruments and is one of the two tree species which is now banned through the Union list. Port Jackson wattle, another tree species on the Union list, so far had only been banned in one country (CY), and in two more legal units due to ban of wattles (Portugal and Galicia, Spain), while the other two listed tree species had not been banned anywhere in Europe before. Overall, 14 of the 24 banned species or species groups are banned in only one country or region, what confirms once more the patchiness of the legislative landscape of NNT in Europe. These uniquely banned species may either not (yet) be considered as a threat, or they actually do not exhibit the same invasive behaviour under different environmental conditions (Vor et al., 2015; Hui et al., 2016), or they are not yet widespread and thus overlooked by the legislator. The latter would be an opportunity, if an EU-wide ban is considered for such a species, because Regulation (EU) No. $1143 / 2014$ highlights the importance of prospect of success and cost-effectiveness of species control measures.

\section{Legislative inconsistencies}

Despite the patchwork of legal instruments of the different sectors, we found few apparent contradictions in the legislation. One example is the region Burgenland (AT), where planting of NNT in forestry takes place freely, but according to legislation the introduction of non-natives into nature would need approval (AT2\$17, Supplementary Table S1) as the exemption for forestry (AT2\$19) that applies to other restrictions in the respective law does not apply to AT2\$17 (in comparison with similar cases in other Austrian regions). Another controversial case is the use of black locust in the region Lombardy (IT). Black locust is referred to in a number of acts and considered from different perspectives. With regard to the regional application of the Regulation (EU) No. 
$1306 / 2013$ (on the financing, management and monitoring of the (AP), farmers can apply for funding of local eradication and control of black locust. This is in line with the fact that this NNT is included in the regional Black list (Regional law n. 10/2008, IT17), which involves the commitment to 'monitor, contain the expansion and eradicate (locally)'. And also a number of LIFE projects aim at tackling black locust (e.g. Motta et al., 2009). On the other hand, another legal instrument (Delibera della Giunta regionale Lombardia 20/02/2008 - No 8/6633) allows for fines in case of damages to black locust plantations on public and private lands. In addition, the production of black locust honey is financially supported by Council Regulation (EC) No 1234/2007 and the honey even has been awarded the Protected Designation of Origin (PDO) (Regulation (EU) No. 1151/2012). Not in the case of Lombardy but in a few other Italian regions, black locust monumental trees are protected by dedicated national laws. As a result, a considerable degree of uncertainty may exist in many countries or regions about what species in fact can be used in forestry, and to what extent.

\section{Conclusions}

Non-native forest tree species are directly or indirectly addressed by a considerable number of legislative acts and orders as well as by a number of effective soft law instruments in most European countries and regions. As a result, stakeholders involved in the introduction of new NNT species or in the use of already introduced NNT for forestry purposes need to be aware and keep constantly informed of their obligations under a complex set of regional, national and European regulations and legislation. While legislation certainly has to evolve and respond to presentday issues, in our opinion, attempts should be made by the legislators to shelter stakeholders from the effects of rapid changes in forest policies and legislation, as forestry requires long-term planning and investments. NNT species already make a significant contribution to the wood supply and provide other useful services in many regions, and they are increasingly considered as an important means of climate change adaptation across Europe. At the same time, there is a continuously increasing awareness of the problems associated with NNT that turn out to be invasive and become a problem for biodiversity and other ecosystem services. Knowledge derived from risk assessments (Bindewald et al., 2019) and guidelines and best practices on dealing with potentially invasive species should therefore become more easily accessible to forestry practice, forest administration and the public. Lists of banned or approved NNT (black lists or white lists) in principle can be an effective and straightforward measure. But on the one hand, regional/national black lists do not prevent the spread across assets that are shared by legal units, like mountain ranges, riparian networks and wetlands. On the other hand, the black listing approach typically ignores the context dependency, i.e. locally differing invasiveness potentials and control options like typical silvicultural management measures (Sitzia et al., 2016). We finally conclude that new coordinated policies are recommended that use science-based unifying principles and criteria and such form a solid basis for tailoring region-specific guidelines for the management of single forest stands and entire landscapes. This would help to reduce the present patchiness of legislation of non-native tree species, promote better integration and consensuality among the political and administrative authorities in charge of forestry and related sectors and reduce uncertainty among forest managers. Most importantly, a science-based policy framework of unifying principles and criteria would allow for rational management of non-native tree species that allows both utilizing advantages of tested NNT and preventing negative environmental impacts of invasive species.

\section{Supplementary data}

Supplementary data are available at Forestry online.

\section{Acknowledgements}

This article is based upon work from COST Action FP1403 (NNEXT) 'Nonnative tree species for European forests - experiences, risks and opportunities' supported by COST (European Cooperation in Science and Technology) (www.cost.eu). We would like to acknowledge all chapter editors of COST Action FP1403 NNEXT 'Country Reports' for the important preparatory work for this study. We wish to thank the following persons in particular for their support in the collection of data: Jean-Philippe Bizoux, Pierre Bouillon, Etienne Branquart, Antonio Brunori, Isabelle Caignet, Luc Derochette, Josef Frydl, Andrea Germani, Alen Kiš, Christian Laurent, Márk Máté, Csaba Mózes, Juha Olavi Honkaniemi, Mariana Pedro, Davide Pettenella, Céline Prévot, Seppo Ruotsalainen, Andreas Socratous, Angela Teani, Annick Terneus, Stein Tomter, Zoran Trailovic, Sauli Valkonen and Miljan Velojić.

\section{Conflict of interest statement}

None declared.

\section{References}

Ammer, C., Arenhövel, W., Bauhus, J., Bolte, A., Degen, B., Dieter, M. et al. 2014 Erhebliche Zweifel an der naturschutzfachlichen Invasivitätsbewertung einiger forstlich relevanter Baumarten. In AFZ-Der Wald.

Bateman, I.J., Harwood, A.R., Mace, G.M., Watson, R.T., Abson, D.J., Andrews, B. et al. 2013. Bringing ecosystem services into economic decision-making: land use in the United Kingdom. Science. 341(6141): 45-50. doi:10.1126/science.1234379.

Bindewald, A., Michiels, H.-G. and Bauhus, J. 2019 Risk is in the eye of the assessor: comparing risk assessments of four non-native tree species in Germany. Forestry 1-16. doi:10.1093/forestry/cpz052.

Blackburn, T.M., Pyšek, P., Bacher, S., Carlton, J.T., Duncan, R.P., Jarošík, V. et al. 2011. A proposed unified framework for biological invasions. Trends Ecol. Evol. 26(7): 333-339. doi:10.1016/j.tree.2011.03.023.

Bolte, A., Ammer, C., Löf, M., Madsen, P., Nabuurs, G.J., Schall, P. et al. 2009. Adaptive forest management in Central Europe: Climate change impacts, strategies and integrative concept. Scand. J. For. Res. 24(6): 473-482. doi:10.1080/02827580903418224.

Brang, P., Pluess, A., Bürgi, A. and Born, J. 2016 Potenzial von Gastbaumarten bei der Anpassung an den Klimawandel. In Wald im Klimawandel. Grundlagen für Adaptationsstrategien. A., Pluess, S., Augustin, P., Brang (eds.). Bundesamt für Umwelt BAFU, pp. 385-405.

Brundu, G. and Richardson, D.M. 2016 Planted forests and invasive alien trees in Europe: a code for managing existing and future plantings to mitigate the risk of negative impacts from invasions. NeoBiota 30, 5-47. doi:10.3897/neobiota.30.7015. 
Brundu, G. and Richardson, D.M. 2017 Code of Conduct for Invasive Alien Trees. T- PVS/Inf (2017) 8. 37th Meeting of the Convention on the Conservation of European Wildlife and Natural Habitats. Standing Committee, Strasbourg, 5-8 December 2017. Strasbourg.

Brus, R., Pötzelsberger, E., Lapin, K., Brundu, G., Orazio, C., Straigyte, L. et al. 2019. Extent, distribution and origin of non-native forest tree species in Europe. Scand. J. For. Res.. 34(7): 533-544. doi:10.1080/02827581.2019.1676464.

Campagnaro, T., Brundu, G. and Sitzia, T. 2018 Five major invasive alien tree species in European Union forest habitat types of the Alpine and Continental biogeographical regions. J. Nat. Conserv. 43, 227-238. doi: 10.1016/j.jnc.2017.07.007.

Correia, H.A., Almeida, H.M., Branco, M., Tomé, M., Montoya, R.C., Di Lucchio, L. et al. 2018. Early survival and growth plasticity of 33 species planted in 38 arboreta across the European Atlantic area. Forests 9(10): 1-18. doi:10.3390/f9100630.

species. T- PVS/Inf (2008) 5 rev. 2nd Meeting of the Group of Experts on Biodiversity and Climate Change. Convention on the Conservation of European Wildlifevand Natural Habitats, Standing Committee, Strasbourg, 16 June 2008

DeepL GmbH. (2017). DeepL. https://www.deepl.com/translator. (accessed on 1 August, 2019).

Derks, J. 2019 An (un)welcome guest-perception of Douglas-fir in seven European countries from the perspectives of forestry and nature conservation. In Douglas-fir-An Option for Europe. What Science Can Tell Us 9. H., Spiecker, M., Lindner, J.K., Schuler (eds.). European Forest Institute (EFI), pp. 105-116.

Ellmauer, T. (ed.) 2005 Entwicklung von Kriterien, Indikatoren und Schwellenwerten zur Beurteilung des Erhaltungszustandes der Natura 2000-Schutzgüter. In Band 3: Lebensraumtypen des Anhangs I der Fauna-Flora-Habitat-Richtlinie. Im Auftrag der neun österreichischen Bundesländer.

Essl, F., Bacher, S., Genovesi, P., Hulme, P.E., Jeschke, J.M., Katsanevakis, S. et al. 2018. Which taxa are alien? Criteria, applications, and uncertainties. Bioscience 68(7): 496-509. doi:10.1093/biosci/biy057.

European Commission 2003 Sustainable Forestry and the European Union-Initiatives of the European Commission. Office for Official Publications of the European Communities.

European Commission Directorate-General for Environment. 2019. Natura 2000. https://ec.europa.eu/environment/nature/natura2000/i ndex_en.htm. (accessed on 1 August, 2019).

FAO 1999 Report of the Second Interim Commission on Phytosanitary Measures, Rome, Italy, 4-8 October 1999. Rome, Italy.

FAO. 2019. FAOLEX Database. http://www.fao.org/faolex/en/ (accessed 1 August, 2019).

Forest Europe. 1993. Resolution H1 General Guidelines for the Sustainable Management of Forests in Europe-Second Ministerial Conference on the Protection of Forests in Europe 16-17 June 1993, Helsinki/Finland.

Forest Europe. 2015a State of Europe's Forests 2015.

Forest Europe. 2015b. Indicator 4.4: Introduced tree species. https://fore steurope.org/introduced-tree-species/.

Gederaas, L., Moen, T.L., Skjelseth, S., and Larsen, L.-K. (eds). 2012. Alien species in Norway - with the Norwegian Black List 2012. The Norwegian Biodiversity Information Centre. doi:citeulike-article-id:13807289.

Genovesi, P. and Shine, C. 2004 European Strategy on Invasive Alien Species. Council of Europe Publishing.

Google LLC. (2016). Google Translate. https://translate.google.at/.

Hasenauer, H., Gazda, A., Konnert, M., Lapin, K., Mohren, G.M.J. (Frits), Spiecker, H. et al. (eds.) 2017 In Non-Native Tree Species for European Forests: Experiences, Risks And Opportunities-COST Action FP1403
NNEXT Country Reports. 3rd edn. University of Natural Resources and Life Sciences.

Hui, C., Richardson, D.M., Landi, P., Minoarivelo, H.O., Garnas, J., and Roy, H.E. 2016. Defining invasiveness and invasibility in ecological networks. Biol. Invasions 18(4): 971-983. doi:10.1007/s10530-016-1076-7.

IUCN. 2019. ECOLEX The gateway to environmental law. https://www.e colex.org/ (accessed 1 August, 2019).

de Jong, W. 2002. Developing swidden agriculture and the threat of biodiversity loss. Agric. Ecosyst. Environ. 62(2-3): 187-197. doi:10.1016/s0167-8809(96)01144-9.

Kormutak, A., Bencat, T. and Slobodnik, B. 2017 Slovakia. In Non-Native Tree Species for European Forests: Experiences, Risks and Opportunities. COST Action FP1403 NNEXT Country Reports, Joint Volume. H., Hasenauer, A., Gazda, M., Konnert, K., Lapin, G.M.J.(.F.)., Mohren, H., Spiecker et al. (eds.). 3rd edn. University of Natural Resources and Life Sciences, pp. 298-305.

Masiero, M., Secco, L., Pettenella, D. and Brotto, L. 2015 Standards and guidelines for forest plantation management: a global comparative study. For. Policy Econ. 53, 29-44. doi:10.1016/j.forpol.2014.12.008.

Medina-Villar, S., Castro-Díez, P., Alonso, A., Cabra-Rivas, I., Parker, I.M., and Pérez-Corona, E. 2015. Do the invasive trees, Ailanthus altissima and Robinia pseudoacacia, alter litterfall dynamics and soil properties of riparian ecosystems in Central Spain? Plant Soil 396(1-2): 311-324. doi:10.1007/s11104-015-2592-4.

Ministère de l'Environnement, du C. et du D. durable. 2016. Mieux valoriser et protéger nos forêts. https://environnement.public.lu/fr/actualite s/2016/02/22_nouveau_code_forestier.html.

Motta, R., Nola, P., and Berretti, R. 2009. The rise and fall of the black locust (Robinia pseudoacacia L.) in the "Siro Negri" Forest Reserve (Lombardy, Italy): lessons learned and future uncertainties. Ann. For. Sci. 66 (4): 410-410. doi:10.1051/forest/2009012.

Nyssen, B., Schmidt, U.E., Muys, B., van der Lei, P.B. and Pyttel, P. 2016 The history of introduced tree species in Europe in a nutshell. In Introduced Tree Species in European Forests: Opportunities and Challenges. F., Krumm, L., Vítková (eds.). European Forest Institute (EFI), pp. 44-54.

Pacheco, F.A.L., Varandas, S.G.P., Sanches Fernandes, L.F., and Valle Junior, R.F. 2014. Soil losses in rural watersheds with environmental land use conflicts. Sci. Total Environ.. 485-486(1): 110-120. doi:10.1016/j.scitotenv.2014.03.069.

Payn, T., Carnus, J.M., Freer-Smith, P., Kimberley, M., Kollert, W., Liu, S. et al. 2015 Changes in planted forests and future global implications. For. Ecol. Manag. 352, 57-67. doi:10.1016/j.foreco.2015.06.021.

Petkova, K., Popov, E., and Tsvetkov, I. 2017. Bulgaria. In Non-Native Tree Species for European Forests: Experiences, Risks and Opportunities. COST Action FP1403 NNEXT Country Reports, Joint Volume, 2nd edition. Edited by H. Hasenauer, A. Gazda, M. Konnert, K. Lapin, G.M.J. (Frits) Mohren, H. Spiecker, M. van Loo, and E. Pötzelsberger. University of Natural Resources and Life Sciences. pp. 40-60.

Pötzelsberger, E. 2018 Should We Be Afraid of Non-Native Trees in Our Forests? University of Natural Resources and Life Sciences.

Pra, A., Brotto, L., Mori, P., Buresti Lattes, E., Masiero, M., Andrighetto, N., and Pettenella, D. 2019. Profitability of timber plantations on agricultural land in the Po valley (northern Italy): a comparison between walnut, hybrid poplar and polycyclic plantations in the light of the European Union Rural Development Policy orientation. Eur. J. For. Res. 138(3): 473-494. doi:10.1007/s10342-019-01184-4.

Riding, M.J., Herbert, B.M.J., Ricketts, L., Dodd, I., Ostle, N. and Semple, K.T. 2015 Harmonising conflicts between science, regulation, perception and environmental impact: The case of soil conditioners from bioenergy. Environ. Int. 75, 52-67. doi:10.1016/j.envint.2014.10.025. 
Rosenkranz, L., Wippel, B. and Seintsch, B. 2012 FFH-Impact: Teil 1: Umsetzung der FFH-Richtlinie im Wald in den Bundesländern. Hamb.

Santiago-Freijanes, J.J., Pisanelli, A., Rois-Díaz, M., Aldrey-Vázquez, J.A., Rigueiro-Rodríguez, A., Pantera, A. et al. 2018. Agroforestry development in Europe: Policy issues. Land Use Policy 76(March): 144-156. doi:10.1016/j.landusepol.2018.03.014.

Schmithüsen, F.J., Herbst, P., and Le Master, D.C. 2000. Forging a new framework for sustainable forestry recent developments in European forest law. IUFRO World Series Volume 10. International Union of Forestry Research Organisations. In ETH Zurich Research Collection. IUFRO Secretariat Vienna; Chair of Forest Policy and Forest Economics. doi:10.3929/ethz-a-010782581.

Schulz, T., Krumm, F., Bücking, W., Frank, G., Kraus, D., Lier, M. et al. 2014. Comparison of integrative nature conservation in forest policy in Europe: a qualitative pilot study of institutional determinants. Biodivers. Conserv. 23(14): 3425-3450. doi:10.1007/s10531-014-0817-0.

Sitzia, T., Campagnaro, T., Kowarik, I., and Trentanovi, G. 2016. Using forest management to control invasive alien species: helping implement the new European regulation on invasive alien species. Biol. Invasions 18(1): 1-7. doi:10.1007/s10530-015-0999-8.

Stanturf, J.A., Madsen, P., Sagheb-Talebi, K., and Hansen, O.K. 2018. Transformational restoration: novel ecosystems in Denmark. Plant Biosyst. 152(3): 536-546. doi:10.1080/11263504.2018.1435586.

Stupak, I., Lattimore, B., Titus, B.D. and Smith, C.T. 2011 Criteria and indicators for sustainable forest fuel production and harvesting: a review of current standards for sustainable forest management. Biomass Bioenergy 35(8): 3287-3308. doi:10.1016/j.biombioe.2010.11.032.

Thürer, D. 2000 Soft law. In Encyclopedia of Public International Law. Elsevier, pp. 452-460.

Tomé, M., Almeida, H., Silva, J.S., and Pinto, G. 2017. Portugal. In Non-Native Tree Species for European Forests: Experiences, Risks and Opportunities-COST Action FP1403 NNEXT country reports, 2nd edition.
H. Hasenauer, A. Gazda, M. Konnert, K. Lapin, G.M.J. (Frits) Mohren, H. Spiecker, M. van Loo, and E. Pötzelsberger. University of Natural Resources and Life Sciences. pp. 342-347.

Tscharntke, T., Clough, Y., Wanger, T.C., Jackson, L., Motzke, I., Perfecto, I. et al. 2012. Global food security, biodiversity conservation and the future of agricultural intensification. Biol. Conserv.. 151(1): 53-59. doi:10.1016/j.biocon.2012.01.068.

Vítková, M., Müllerová, J., Sádlo, J., Pergl, J. and Pyšek, P. 2017 Black locust (Robinia pseudoacacia) beloved and despised: a story of an invasive tree in Central Europe. For. Ecol. Manag. 384, 287-302. doi:10.1016/j.foreco.2016.10.057.

Vor, T., Spellmann, H. and Bolte, A. 2015 In Potenziale und Risiken eingeführter Baumarten (Potentials and Risks of Introduced Tree Species). C., Ammer (ed.). Deutscher Forstwirschaftsrat.

van Wilgen, B.W., and Richardson, D.M. 2014. Challenges and trade-offs in the management of invasive alien trees. Biol. Invasions 16(3): 721-734. doi:10.1007/s10530-013-0615-8.

Wilson, J.R.U., Caplat, P., Dickie, I.A., Hui, C., Maxwell, B.D., Nuñez, M.A. et al. 2014. A standardized set of metrics to assess and monitor tree invasions. Biol. Invasions 16(3): 535-551. doi:10.1007/s10530-013-0605-X.

Wilson, J.R.U., Faulkner, K.T., Rahlao, S.J., Richardson, D.M., Zengeya, T.A., and van Wilgen, B.W. 2018. Indicators for monitoring biological invasions at a national level. J. Appl. Ecol. 55(6): 2612-2620. doi:10.1111/1365-2664.13251.

Young, J.C., Marzano, M., White, R.M., McCracken, D.I., Redpath, S.M., Carss, D.N. et al. 2010. The emergence of biodiversity conflicts from biodiversity impacts: characteristics and management strategies. Biodivers. Conserv. 19(14): 3973-3990. doi:10.1007/s10531-010-9941-7.

Zabel, F., Delzeit, R., Schneider, J.M., Seppelt, R., Mauser, W., and Václavík, T. 2019. Global impacts of future cropland expansion and intensification on agricultural markets and biodiversity. Nat. Commun. 10(1): 1-10. doi:10.1038/s41467-019-10-775-z. 